\title{
Instead of negationism. The symbolic topography of the former Warsaw ghetto vis-à-vis Holocaust narratives
}

Polish Holocaust narratives after 1945, by and large, blurred the identity of the victims. The following methods were employed: humanist universalisation, anti-fascist universalisation, 'Polonisation', and finally 'Christianisation'. In the sequence of narratives, the following were the victims: People, victims of fascism, Poles, members of European nations of various religious denominations, with special emphasis placed on Christians. ${ }^{1}$ After the decade-long symbolic battle for the Carmelite cloister and the Auschwitz gravel pit, even if the so-called 'papal cross' was not removed from the area adjacent to the camp, and even if the cross that towers over Birkenau remained, the Holocaust was 'returned' to the Jews. ${ }^{2}$

Does a narrative about the Holocaust as a crime perpetrated on the Jews threaten the dominant narration about the past of the Polish majority? Yes and no. It does, as long as one defines the Holocaust as a crime of the German state perpetrated in occupied Europe. On the other hand, it begins to be a fundamental threat, as Jan Tomasz Gross postulates, if one considers that the Holocaust was also (or perhaps primarily?) "a mosaic of distinct episodes, improvised by local decision-makers, and hinging on unforced behaviour, rooted in motivations that can only be guessed, of all of those who were near the murder scene at

${ }^{1}$ Cf. for example: Lucy Dawidowicz, "Appropriating the Holocaust: Polish Historical Revisionism," in The Holocaust and the Historians (Cambridge, MA: Harvard University Press, 1981), pp. 88-124; Jonathan Heuner, Auschwitz, Poland, and the Politics of Commemoration, 1945-1979 (Athens: Ohio University Press, 2003); Piotr Forecki, "Zbiorowe zapominanie Zagłady w PRL," in idem, Od "Shoah" do "Strachu”. Spory o polsko-żydowska przeszłość i pamięć w debatach publicznych (Poznań: Wydawnictwo Poznańskie, 2010), pp. 13-114; Jean-Charles Szurek, “Le camp-musée d'Auschwitz en 1989," in idem, La Pologne, les Juifs et le communisme (Paris: Michel Houdiard Éditeur, 2010), pp. 11-29; “Les doutes de l'antifascisme. Table Ronde, 16 février 1990," in ibidem, pp. 30-51.

${ }^{2}$ Cf. Piotr Forecki, "Spory o symboliczne panowanie nad Auschwitz-Birkenau," in idem, Od "Shoah" do "Strachu"..., pp. 167-280; Geneviève Zubrzycki, The Crosses of Auschwitz: Nationalism and Religion in Post-Communist Poland (Chicago: University Chicago Press, 2009). 
the time." ${ }^{3}$ In the latter case the majority practices of the local communities should be defined as "supplementing and tightening of the Nazi machinery of destruction." 4 The Holocaust as a German state crime and the local socio-cultural context began to stimulate one another, which may be termed synergy, the cooperation of factors that increase each other's efficiency. This observation helps one to understand better why the stake in the Polish Holocaust narrative was and in an overwhelming majority of cases still is the image of Poland and Poles.

I am interested in the strategies of managing the symbolic space of the former Warsaw ghetto. Symbolic topography is a form of narration about history and group identity, or the identity of groups, which do not so much inhabit a given territory but have access to the means of controlling space. That is why the symbolic arrangement of an area marvellously reveals the relations of power (dominance/subservience) and the character of 'imaginings' that constitutes a community by including some and excluding others. ${ }^{5}$ In the case of the former Warsaw ghetto, one deals with a veritable laboratory situation. The Jewish Warsaw on the left bank of the River Vistula was almost completely razed to the ground by the Germans during the Jewish uprising and during systematic demolition after the rising was suppressed. Hence there are virtually no traces of the resistance of matter in the form of tangible traces of the Jewish past of the

\footnotetext{
${ }^{3}$ Jan Tomasz Gross, Neighbors. The Destruction of the Jewish Community in Jedwabne, Poland (Princeton and Oxford: Princeton University Press, 2001), p. 125. "The Shoah has been portrayed in scholarly literature as a phenomenon rooted in modernity. We know very well that in order to kill millions of people, an efficient bureaucracy is necessary, along with a (relatively) advanced technology. But the murder of the Jedwabne Jews reveals yet another, deeper, more archaic layer of this enterprise. I am referring not only to the motivations of the murderers, after all, Jedwabne residents and peasants from the Łomża District could not at that time have managed to soak up the vicious anti-Jewish Nazi propaganda, even if they had been willing and ready, but also to use primitive, ancient methods and murder weapons: stones, wooden clubs, iron bars, fire, and water; as well as the absence of organisation. It is clear, from what happened in Jedwabne that one must approach the Holocaust as a heterogeneous phenomenon. On the one hand, one must be able to account for it as a system, which functioned according to a preconceived (though constantly evolving) plan. But, simultaneously, one must be able to see it as a mosaic of discrete episodes, improvised by local decision-makers, and hinging on unforced behaviour, rooted in unknown motivations, of all of those who were near the murder scene at the time. This makes all the difference in terms of assessing responsibility for the killings, as well as calculating the odds for survival that confronted the Jews" (ibidem, pp. 124-125).

${ }^{4}$ Cf. Elżbieta Janicka, Tomasz Żukowski, “Ci nie są z ojczyzny naszej,” Gazeta Wyborcza, 29-30 October 2011.

${ }^{5}$ In Polish literature, the matter of the relationship between the power and structuring of a community on the example of arrangement of symbolic space, is analysed by, i.a., Bohdan Jałowiecki (cf. idem, "Przestrzeń jako pamięć", Studia Socjologiczne 2 [1985]) and Lech M. Nijakowski (cf. idem, Domeny symboliczne. Konflikty narodowe i etniczne w wymiarze symbolicznym [Warsaw: Wydawnictwo Naukowe Scholar, 2007]). 'Symbolic space' in Nijakowski means "territory over which a given group has symbolic dominion" (ibidem, p. 108).
} 


\section{Studies}

city. My research question concerns the way in which the narration enclosed in the symbolic topography treats material knowledge of the history of the place and of the history of the Holocaust.

\section{Post-Jewish space ${ }^{6}$}

The 'marking of space' is a category used by Manuel Castells to describe a city as a form, or a set of forms, of symbolic expression. The city is, thus interpreted, is an area of play for symbolic power, which manifests itself in the efforts to mark space, be it through symbols of power or by the tangible reality of values. ${ }^{7}$ Sławomir Kapralski formulated it more poignantly and dropped the category of playground in favour of that of battlefield. In the model he describes there is a rivalry between communities that inhabit the same physical space for a symbolic and other domination over a territory:

In the model he describes there is a rivalry between communities that inhabit the same physical space for a symbolic and other domination over a territory:

Thus landscape becomes battlefield: a place in which groups compete for the fullest possible representation of their identities, trying, according to the means at their disposal, to structure the landscape and invest it with the meaning that is appropriate with respect to their identities. ${ }^{8}$

Urban anthropology makes one aware of the typology of relations between urban space and cultural memory, with three major figures: palimpsest, trace and the battlefield.

They have one thing in common: all of them recognise, to a greater or lesser extent, that place and time are ruled by the logic (and politics of the memory's location in cultural and collective memory. It comprises both the material artefacts (plaques and monuments that commemorate events, people, and increasingly frequently animals, museums, necropolises, and murals, as well as what does not exist in the material dimension, empty spaces, holes, gaps, and ruins, which leave traces of the absent past, and finally what belongs in the performative sphere, that of actions,

\footnotetext{
${ }^{6}$ Konrad Matyjaszek's term, which he developed when discussing Diana Pinto's concept of Jewish space, cf. idem, "Przestrzeń pożydowska," Studia Litteraria et Historica 2 (2013): 130-147.

${ }^{7}$ Manuel Castells, The Urban Question: A Marxist Approach, trans. by Alan Sheridan (Cambridge, MA: MIT Press, 1977). Cf. overview of the source literature: Ewa Kaltenberg-Kwiatkowska, "O oznaczaniu i naznaczaniu przestrzeni miasta," Przegląd Socjologiczny vol. 60, 2/3 (2011): 135-165.

${ }^{8}$ Sławomir Kapralski, "Battlefields of Memory: Landscape and Identity in Polish-Jewish Relations," History and Memory vol. 13, 2 (Autumn-Winter 2001): 35-58.
} 
historical performances, memorial rituals, individual and collective ceremonies. ${ }^{9}$

Yet, the battlefield category seems to me a superior category to that of palimpsest ${ }^{10}$, and trace. Palimpsest is sometimes used or even produced for tactical purposes and, as trace, it is sometimes used by various groups as an instrument of legitimisation.

The spatial model that Kapralski proposes, in its ideal variant, entails an equal status of the inhabiting groups. He is however aware that: "In the case of a minority group the situation is more difficult because the dominant group tends to monopolise and control the means of symbolic expression to support its claim to the territory as its 'property'"'11 Thus Kapralski is interested in the asymmetrical relation between the Polish majority and the Jewish minority. Thus he adds another reservation to the already modified ideal model. Even if he does no probe deeply into the causes of the situation in question, he is perfectly aware of its critical character. He stresses that he is discussing a case where a fight for a given territory continues, even though the minority group has ceased to exist.

Landscape becomes an arena of both remembering and forgetting, but now it represents only the memory of the surviving group. In such a situation, the memory of the group that perished and its material representations can be manipulated in an unrestricted way by those who remained. Landscape preserves what the group wisheants to remember; that which the group wisheants to forget is destroyed, neglected or preserved in a distorted way. ${ }^{12}$

One part of the analysed relationship is thus a minority, which is not only dominated, but one that is also consistently being erased and ultimately eradicated, and also statistically absent. One may take a closer look at the mode of this absence. Statistical absence overlaps with nominal absence. In the light of Polish law, the few people with a Jewish, Jewish-Polish or Polish-

${ }^{9}$ Elżbieta Rybicka, "Memory and city. A palimpsest vs. A battleground," Teksty Drugie 5 (2011): 202.

${ }^{10}$ The metaphor of palimpsest is given different meanings: David Harvey used his term to demonstrate how different social and economic layers of cities' history are overlapping (cf. idem, "Kwestia urbanizacji", trans. by Andrzej Majer, Kultura i Społeczeństwo 4 [1996]). One of Andreas Huyssen's books is subtitled Urban Palimpsest and the Politics of Memory (2003), which shows how sensitive urban space is to external instrumentalisation and legitimisation practices, Felix Ackermann titled his monograph on Grodno Palimpsest Grodno (2010), thus indicating the multitude of coexistent national, political and religious narrations in the city. Similar symbolism can be found also in Régine Robin (2002) in her book dedicated to the memory of Berlin" (Magdalena Saryusz-Wolska, "O źródłach pamięci miasta w nowoczesności," Kultura i Społeczeństwo 4 [2011]: 98-99).

${ }^{11}$ Kapralski, "Battlefields of Memory..., p. 2.

${ }^{12}$ Ibidem. 


\section{Studies}

Jewish identity do not have the status of a national minority. Because they do not meet one legally required criterion, that is they do not speak their own language. (In contemporary Poland Jews are a religious minority. Reductionism and tight definitions at the level of the linguistic image of the world can serve as a metaphor of both the so-called Jewish place and of the condition of the Polish majority culture. The lack of a separate language literally coincides with the metaphorical lack of their own voice: a votum separatum. Minority messages typically conform to the majority perspective; they reproduce and thus legitimise the majority's position. ${ }^{13}$ Particularly spectacular examples of this state of affairs can be found in situations where representatives of Jewish institutions publicly deny the anti-Semitic character of anti-Semitic incidents. ${ }^{14}$ This practice yields a repeated comical effect with an additional act of humiliation:

${ }^{13}$ Mimicry may have protective functions, but it can also be the result of internalisation of majority's point of view (cf. Sander L. Gilman, Jewish Self-Hatred: Anti-Semitism and the Hidden Language of the Jews [Baltimore: The Johns Hopkins University Press, 1986]); Joanna Tokarska-Bakir, “'Hassliebe'. Żydowska samonienawiść w ujęciu Sandera L. Gilmana [część pierwsza: od Hermana z Moguncji do Johannesa Pfefferkorna]," Studia Litteraria et Historica 2 [2013]: 27-59; Bożena Keff, “Wuj Jankiel," Studia Litteraria et Historica 2 [2013]: 60-75).

${ }^{14}$ In relation to this, characteristic were endeavours, after the attack on the Chief Rabbi of Poland by a nationalist shouting "Poland for the Poles!" The culprit has a different opinion on his own motivations than the rabbi, but he continues to produce anti-Semitic 'arguments' (cf. Gąbka [pseudonym of the author], Kilka pytań do Karola Golińskiego, który 'pobił' naczelnego rabina Polski Schudricha, http://www.insomnia.pl/_pobicie_rabina...-t202128.html, from 27 September 2006, access 26 August 2013). Michael Schudrich's claim, that "it was an isolated incident" was in contrast with the fact that in the National Police Headquarters "a special group was created, which will not only take care of the case of the attack on Rabbi Schudrich, but also similar incidents." (cf. PAP, Prezydent spotkał się z Naczelnym Rabinem Polski, http://wiadomosci.wp.pl/kat,1342,title,Prezydent-spotkal-sie-z-Naczelnym-RabinemPolski,wid,8329483,wiadomosc.html?ticaid=11131a from 29 May 2006, access 26 August 2013). Rabbi's U.S. citizenship additionally activated Polish need to improve its image: "Authorities and the police are doing their best to show how important for them it is to contradict Poland's image as an anti-Semitic country. After the attack on Michael Schudrich, President Lech Kaczyński invited the Chief Rabbi of Poland to the Presidential Palace and assured him that anti-Semitic acts are not and will not be tolerated in Poland. This kind of meeting is unprecedented. The chief of the Ministry of Interior and Administration, Ludwik Dorn, decided that the investigation into the attack will be taken over by the diplomatic section of the investigation department of the National Police Headquarters." The rabbi took part in the public relations action: "He also supported the Polish government, which was accused by The New York Times of tolerating anti-Semitism. The authors of the article assert that Poland is perceived internationally as a homophobic, nationalistic and anti-Semitic country. The chief rabbi disagrees with this. He claims that the current government indeed must specify its politics on many matters, but those concerning threatening acts performed on national and religious minorities are not one of them." (Anna Pająk, Nie popuszczq, http://www.wprost.pl/ar/92024/ Nie-popuszcza/ - from 30 June 2006, access 26 August 2013). 
- This staggers the imagination. When I visited cemeteries I often saw demolished tombstones or 'Jude raus' inscriptions, but never have I seen such devastation, stresses Piotr Rytka-Zandberg, of the Warsaw Jewish Religious Community. [...] In my opinion this is not an act of anti-Semitism but of mindless vandalism. ${ }^{15}$

This ritual of subordination, virtually unthinkable in contemporary Germany or France, is practised by Polish Jews in Poland in other spheres of life as well.

This is all happening in a liberal democracy, which considers equal rights of citizens to be obvious and self-evident. Thus such situations cannot be understood without references to socio-cultural underpinnings and the historical context. These are the cause of the discrepancy between the legal and formal order and the actual state of affairs. They determine the contemporary situation of Jews in its qualitative and quantitative aspects. Suffice it to say that it was not the Holocaust, understood as a German crime perpetrated in occupied Poland, which ended the Jewish presence in Poland. At the various stages of the Holocaust, the 'ghettoisation', mass-scale extermination and the Polish-German and German-Polish hunting of the Jews (Ger. Judenjagd) ${ }^{16}$ - about 90 per cent of the pre-war Jewish population were killed. On the pre-war Polish territory about 50,000 Jews survived: "most of them lived to be liberated in death camps or labour camps. Many fewer survived hiding in forests, due to the help of Poles, or in partisan units, particularly in the eastern part of the country."17

Following repatriation from the Soviet Union, there were at least 250,000 Jews in the post-war borders of Poland. The so-called 'disappearance' of Jews from Poland was a result of the post-war, grass-root and top-to-bottom symbolic and physical anti-Semitic violence of the dominant group. Anti-Semitic attitudes and behaviour reflected, in turn, the code of the majority culture formed before

${ }^{15}$ Tomasz Urzykowski, “Egzekucja na macewach. Kirkut w Błoniu zniknął," Gazeta Wyborcza, supplement Gazeta Stołeczna, 27-28 April 2013.

${ }^{16}$ Cf. Jan Grabowski, Judenjagd. Polowanie na Żydów 1942-1945. Studium dziejów pewnego powiatu (Warsaw: Stowarzyszenie Centrum Badań nad Zagładą Żydów, 2011 [in English: Hunt for the Jews: Betrayal and Murder in German-Occupied Poland, Bloomington: Indiana University Press, 2013]). Members of titular communities from the territory of Western Ukraine (during the Second Polish Republic, it was called Eastern Galicia) and Lithuania have also taken part in Judenjagd.

${ }^{17}$ Dzieje Żydów w Polsce 1944-1968. Teksty źródłowe, compiled by Alina Cała and Helena Datner-Śpiewak (Warsaw: ŻIH, 1997), pp. 166-167. Grzegorz Berendt estimates the number of survivors from the Aryan side in the General Government at 40,000-60,000, the number of the survivors from the Nazi concentration camps in turn at 36,000. According to his findings, the survivors comprised together 10-15 per cent of 'the pre-war number of Polish Jews in the country', i.e. 350,000-525,000. The most numerous group, comprising over 300,000 people, consisted of those, who were in the USSR during the war (cf. Grzegorz Berendt, "Straty osobowe polskich Żydów w okresie II wojny światowej," in Polska 1939-1945. Straty osobowe i ofiary represji pod dwiema okupacjami, ed. Wojciech Materski and Tomasz Szarota [Warsaw: IPN, 2009], p. 75). 
the Holocaust, morally sanctioned by the majority religion and still unresolved in the social dimension.

\section{Symbolic strategies}

Thus the contemporary battle for symbolic domination of the space of the former Warsaw ghetto is taking place after the war. What was left standing on the battlefield was the majority, hegemonic and homogenous. Therefore, the "concept of urban landscape of memory as a field of conflict, where various remembrance discourse practices clash"18 cannot be applied here. The conflict potential is not activated at all, because no alternative narration takes place. It is so because the dominant group dictates the conditions of access to the common space. It also determines the narrative framework, which all the 'actors of memory' have so far conformed with. The narrative framework in the field of discourse analysis would correspond with the social memory framework in the field of research of socio-cultural memory, started by Maurice Halbwachs. Halbwachs, who situates his reflection on the extension of the Durkheimian vision of the social world, pointed at the socially generated cultural standards, which define what is remembered/forgotten, and how. ${ }^{19}$

Because control over the physical and the symbolic space of the former Warsaw ghetto is solely in the hands of the dominant culture, strategies such as silencing or removing or replacing signs of life and death of the minority are no longer necessary. Thus the situation deviated from a pattern, in which "The co-existence of both groups was marked by Polish efforts aimed at minimising the Jewish presence in the landscape defined by the politically dominant PolishCatholic majority." 20

The elimination or silencing the Jewish past of the city and of the country are strategies that have been on the wane since the $1980 \mathrm{~s}^{21}$ It was then that

\footnotetext{
${ }^{18}$ Rybicka, "Pamięć i miasto...," p. 210.

${ }^{19} \mathrm{Cf}$. Maurice Halbwachs, On Collective Memory, trans. Lewis A. Coser (Chicago: University of Chicago Press, 1992). Post-structural, feministic and postcolonial discussion; as approached by Durkheimian-Halbwachs, cf. Sławomir Kapralski, "Pamięć, przestrzeń, tożsamość. Próba refleksji teoretycznej," in Pamięć, przestrzeń, tożsamość, ed. Sławomir Kapralski (Warsaw: Wydawnictwo Naukowe Scholar, 2010), pp. 16-18. It seems, however, that it refers to an intra-systemic criticism demanding more of Durkheim than can be found in Durkheim and more of Halbwachs than can be found in Halbwachs, similar to Pierre Bourdieu's enlightenment postulate, based on Adorn's and Horkheimer's thought.

${ }^{20}$ Kapralski, "Battlefields of Memory...," p. 3.

${ }^{21}$ Amongst publications from that period, Poland's People Republic's authorities gave a primary meaning to a photo album: Monika Krajewska, Time of Stones, introduction by Anna Kamieńska (Warsaw: Interpress, 1983) (language versions: Polish, English, French, German). Krajewska's album unintentionally suited the authorities' needs, and at the same time reflected changes made at grass-roots levels in which the author participated, and it was in accordance with the authentic social expectations. Hanna Krall spoke critically about these social
} 
we saw a certain kind of consensus between the rulers and opposition milieus. The different motives of either party could have been agreed upon in light of the common part, namely the care for the image of Poland and the Poles. ${ }^{22}$ This $n$ does no mean that all the participants shared the image motive. ${ }^{23}$ Nonetheless, the care for the collective image manifested itself powerfully in milieus connected

expectations: "This interest in Jews that part of the youth and Polish intelligentsia takes, roots in the fact, that the Jews were the part of Poland which is nowadays mythologised." ("Lewica powinna marzyć. Z Hanną Krall rozmawia Adam Krzemiński”, Polityka 4 (1991), quote: Reporterka. Rozmowy z Hanna Krall, choice, composition, additions and documentation by Jacek Antczak (Warsaw: Rosner \& Wspólnicy, 2007, p. 132). At the same time, up to 1985, another work was being created, which was published at the turn of 1989: Małgorzata Niezabitowska, Tomasz Tomaszewski, Remnants - The Last Jews of Poland (New York: Friendly Press, Inc., 1986). Moreover, "in the years 1980-1986, 171 'Jewish' books were published, and in the next two years, 123" (Michael C. Steinlauf, Bondage to the Dead: Poland and the Memory of the Holocaust [New York: Syracuse University Press, 1997]). The matter of similarities and differences in the offers of the legal publishing associated with the authorities, legal publishing dissociated from the authorities (e.g. Znak or KUL) and illegal underground publishing, is yet to be analysed.

${ }^{22}$ Michael C. Steinlauf indicated the phenomenon of image alliance existing despite partitions: "Władysław Bartoszewski, a founding member of Żegota, was a Catholic activist who had been imprisoned in Poland during the Stalinist period and remained a resolute opponent of the succeeding Communist governments. In 1963, citing as his motive western stereotypes of Poles as collaborators in the murders of Jews, Bartoszewski issued a call in the leading Polish Catholic and émigré press for material documenting Polish aid to Jews during the war. Bartoszewski, who apparently did not experience the difficulties encountered by Michał Borwicz in assembling such material fifteen years previously, had two editions of collections of testimonies, Ten jest z ojczyzny mojej [This is of my fatherland], published by the Catholic publisher Znak [Sign]. But Bartoszewski was soon cited in the government press, and in 1970 the government publishing house Interspersed issued a narrative by Bartoszewski, in English, French, and German editions, based on the testimonies. This curious and temporary rapprochement between otherwise implacable enemies (by the 1980s Bartoszewski was again persona non grata in Poland) is another sign of the degree to which, as the generation of the war years came to power, issues connected with the Polish experience of the Holocaust, and indeed only these issues, had the power to transcend the most formidable political differences." (Steinlauf, Bondage to the Dead..., p. 84). Dariusz Libionka gives a similar date, 1963, for the beginnings of the image alliance existing despite partitions and underlines immigrant communities' participation in it, e.g. Parisian magazine Kultura [Culture]. At that time, the authorities started mentioning the merits of every kind of Poles, including priests (cf. Dariusz Libionka, "Polskie piśmiennictwo na temat zorganizowanej i indywidualnej pomocy Żydom (1945-2008)," Zagłada Żydów. Studia i materiały 4 (2008): 30-31).

${ }^{23}$ On the side of the supporters of the system, Zygmunt Kałużyński was one of those who did not follow the image motive, on the side of the authority's opponents there was, for example, Jacek Kuroń (cf. Piotr Forecki, “'Biedni Polacy' patrzą na 'Shoah'. Przywracanie pamięci w kraju świadków," in idem, Od „Shoah” do „Strachu”..., pp. 115-165). Members of Social Committee for Care of Cemeteries and Monuments of Jewish Culture of the Society for Care of Monuments (Społeczny Komitet Opieki nad Cmentarzami i Zabytkami Kultury Żydowskiej) should be included in this group. 
with the ruling group and among the leaders of public opinion and also during the debate regarding Claude Lanzmann's film Shoah (1985). Ultimately the two parties succeeded, among others, in erecting a monument designed by Hanna Szmalenberg and Władysław Klamerus at the former Umschlagplatz, and in setting up the Memorial Route of Jewish Martyrdom and Struggle in Warsaw designed by Zbigniew Gąsior, Stanisław Jankowski 'Agaton' and Marek Moderau.

Both projects were completed in 1988. Since then the number of so-called Jewish remembrances has increased. Most of them are signs that refer to the ghetto history and the Holocaust. Most of them appeared during the independent Third Polish Republic and date back to after the year 2000. Thus the point is the quality not the quantity: the decorations, content, explanations, scale, situation in the physical and symbolic space (in relation to other remembrances), as well as in the mode of functioning, that is in the social practices that focus on a given artefact.

The contemporary narration of the past in the space of the former Warsaw ghetto is constructed in such a way that suggests not only coexistence and pluralism, but is in effect a polyphonic community of memory: of the minority and the majority, of the Jews and the Poles. But in fact one deals with homophony. A more profound analysis of the symbolic stakes that are played for on a given territory reveals a logic of domination that employs violence and exclusion. The principles of construction of the ostensibly common and communal narration may be seen on the example of what the hegemonic and homogenous system of identity and imagination identifies as something that does not fit within it, and by the same token as potentially disruptive and substantially threatening. What we are discussing are signs that suggest the possibility of a different narration. What kind of threat are we talking about, since, despite the presence of signs of an alternative order an alternative narration remains unarticulated? Firstly, their very appearance in a homogenous horizon of elements perceived as heterogeneous reveals rules of the system and opens the way for their questioning. Secondly, it is tantamount to relativisation and a change of the system's status, from obvious and transparent to arbitrary and problematic. The 'natural' and 'neutral' order of things proves to be a construct, one of many possible ones.

In order to preserve the belief in the singularity of the system and the lack of any alternative to it a potentially difficult element can be silenced or removed from sightand, possibly, be replaced with a neutral or polemic element. Should the problematic element be admitted into public space, it ought to be accompanied by a neutralising interpretation, which deprives it of its distinctive features. Neutralisation often takes the form of disqualification if not compromising. This type of symbolic liquidation is tantamount to its being absorbed by the system, without changing the rules of the latter. Absorption should not be confused with inclusion, which would require changing the rules of the system, and thus a change of the system tout court, in other words, a revolution in the sphere of the majority identity and dominant imagination. 
Symbolic liquidation requires pacification procedures, among which the most frequently employed are: utterance based on concealment and surrounding (typically with a polemical intention). Once popular procedures: simple concealment, elimination and substitution (also polemic as a rule), consisted in repressing signs. In the case of utterance based on concealment and surrounding, one deals with operations directed not so much at signs as at their referents. In other words, here one deals with an attempted retroactive correction, doomed to fail as does any kind of prevention attempted post factum. What is done is done and cannot be undone. Referents are not susceptible to persuasion. Thus out of necessity, the Polish defence of a lost cause consists not so much in defusing semantic charges as in masking their potential that threatens the majority narration. The changes in the arrangement of the symbolic space of the former Warsaw ghetto introduced so far are rather superficial. The majority narrative remains entrenched on its old positions and, despite actual domination, still defines itself in front-line terms: as one that is under attack and forced to defend itself. The stabilising and protective dimension of verification procedures is indeed defensive, but it is defence through attack. One telling example of pacifying procedures is the form and the arrangement of remembrance located along Stawki Street.

\section{The sculpture and architecture of identity}

Stawki Street is where the reloading point (Ger. Umschlagplatz) was located, from where the Nazis deported Jews detained in the Warsaw ghetto to labour camps, but primarily to the gas chambers of Treblinka and Majdanek. ${ }^{24}$ In 1988 a monument-grave slab of the Jewish Warsaw was erected there. The sign of memory and the place are in a relationship of direct simple attribution. Several years later, in 1995, another monument was erected in the same street: the Monument to the Fallen and Murdered in the East, with 'Russianism' in its very name. In the Polish name of the monument the dative is used instead of the correct genitive. The structure commemorated events unrelated to this place, to the street, the district and the city, and might as well be located in a different part of the capital. This is an example of indirect, arbitrary attribution.

\section{a) The Umschlagplatz}

The initiative to commemorate Jews deported to their death was born on 19 April 1985 among the members of the Social Committee for Care of Cemeteries and Monuments of Jewish Culture of the Society for Care of Monuments. At that time the Committee members included: Hanna Szmalenberg and Stanisław Krajewski (active opposition members) and Teresa Prekerowa and Jan Jagielski

${ }^{24}$ On the history of the street and the place cf. Jacek Leociak, Stawki, Spojrzenia na warszawskie getto 6 (Warsaw: Dom Spotkań z Historią, 2011): 21-27. 
(who supported the opposition. They decided to use the $45^{\text {th }}$ anniversary of the Warsaw ghetto uprising as an argument in their talks with the authorities. For the authorities the celebrations of the Jewish uprising had an enormous prestige importance. Furthermore, Wojciech Jaruzelski and his men were seeking rehabilitation in the international arena. According to Hanna Szmalenberg, the "government was making advances to Israel". So the matters took on a smooth course:

On 11 July [1985] the Committee presented its plans to the deputy mayor of Warsaw [Mr] Michał Szymborski, who fully accepted the Committees intentions and guaranteed organisational and financial assistance in their implementation. The Committee conducted consultations with Marek Edelman, who fully accepted the idea of a Monument-Wall at the Umschlagplatz and the Memorial Route of Jewish Martyrdom and Struggle and gave the members plenty of information. In June 1986, the design of the Wall-Monument was approved in artistic terms by the Chief Artist of Warsaw, Stanisław Soszyński, who expressed his "recognition of its high artistic features". The design of the Wall-Monument and if the Memorial Route were also approved by the Provincial Commission for the Protection of Struggle and Martyrdom Sites [...]. ${ }^{25}$

The liaising between the initiators and the authorities was conducted by Stanisław Jankowski 'Agaton', an architect, urban planner, former aidede-camp of Tadeusz Bór-Komorowski, one of the chief planners of the MDM housing development in downtown Warsaw, and the West-East Route. The MDM (Marszałkowska Dzielnica Mieszkaniowa) and the West-East Route (Trasa $W-Z$ ) rate among the leading achievements of Warsaw's reconstruction after the war-time destruction. They are classified as examples of social realism in architecture, and were used to legitimise the post-war regime. Jankowski was a holder of prestigious state decorations, and wrote a widely popular book $Z$ fałszywym ausweisem $w$ prawdziwej Warszawie [Carrying a false Ausweis in real Warsaw] (3 editions: 1980, 1984/1985, 1988). He was predestined to play this role, as he was a natural, born activist and had a thorough orientation in the realities and the day and the personae involved, namely the so called 'contacts'. One of his unquestioned advantages was his doubly emblematic biography of a Home Army hero and a decorated builder of the Polish People's Republic. He also proposed that the members of the Commission for the Memory Sign at the Umschlagplatz, which was composed of people who are competent on the one hand, and who have a certain credibility in the eyes of national and foreign

${ }^{25}$ Aleksander Gieysztor, Stanisław Jankowski, Sprawozdanie z działalności Komisji Towarzystwa Opieki nad Zabytkami do spraw Znaku Pamięci Umschlagplatz za okres od lutego 1987 do września 1988, p. 3 - document dated on 21 October 1988, from the files of the Register of Historic Monuments Department from Emanuel Ringelblum Jewish Historical Institute (Dziat Dokumentacji Zabytków Żydowskiego Instytutu Historycznego im. Emanuela Ringelbluma). 
decision makers. ${ }^{26}$ Aleksander Gieysztor became chairman, and his deputy was Szymon Szurmiej, who maintained contact with the World Jewish Congress. ${ }^{27}$ The Commission's secretary was Jankowski himself, which enabled him to coordinate the entire diplomatic operation. The treasurer was Teresa Prekerowa, who, because of her illness, was eventually replaced by Małgorzata Wołyńska. ${ }^{28}$ The Commission operated from 12 February 1987 to 21 October 1988. There was no competition for the monument's design. The authorities were presented with Hanna Szmalenberg's design, who then invited the sculptor Władysław Klamerus to collaborate on the project.

The combined projects were financed by the Capital City Warsaw and the American Joint Distribution Committee. The block of black syenite that caps the monument was a later gift of the People and the government of Sweden. The committee to celebrate the $45^{\text {th }}$ anniversary of the Warsaw Ghetto Uprising was chaired by the chairman of the Council of State, Henryk Jabłoński. He also cut the ceremonial ribbon at the unveiling ceremony of the Umschlagplatz monument on 18 April 1988, assisted by the honorary company of the Polish Army to the tune of the Polish national anthem and La Varsovienne, the latter being emblematic for the Polish romantic tradition of insurrections in the fight for independence. ${ }^{29}$ This

${ }^{26}$ I have gathered these pieces of information from a co-initiator and co-author of the Hanna Szmalenberg monument and current president of Caring for Cemeteries and Jewish Culture Relics Social Committee, Jan Jagielski.

${ }^{27}$ Aleksander Gieysztor - historian, former member of The Bureau of Information and Propaganda of the Home Army (Biuro Informacji i Propagandy Komendy Głównej Armii Krajowej) - was at the time the manager of the Royal Castle in Warsaw, a member of Advisory Board to the Chairman of Poland's People's Republic Council of State (Rada Konsultacyjna przy Przewodniczacym Rady Państwa PRL), Wojciech Jaruzelski, and a member of The Council for the Protection of Struggle and Martyrdom Sites (Rada Ochrony Pamięci Walk i Męczeństwa). Whereas Szymon Szurmiej, an actor and theatre director, former exile and inmate of the Soviet labour-camps, was the head of the Jewish Theatre in Warsaw, the chairman of The Jewish Socio-Cultural Association in Poland (Towarzystwo Społeczno-Kulturalne Żydów w Polsce), a member of The Polish United Workers' Party (Polska Zjednoczona Partia Robotnicza, PZPR), and a Sejm's ninth term deputy in Poland's People's Republic.

${ }^{28}$ The commission consisted also of: Stefan Bergman (employee of the Jewish Historical Institute (Żydowski Instytut Historyczny, ŻIH)), Stanisław Soszyński (Warsaw’s chief artist), Tadeusz Bilewicz (vice-chairman of Polish Society of the Righteous Among the Nations (Polskie Towarzystwo Sprawiedliwych wśród Narodów Świata)), Stanisław Krajewski (a member of the Social Committee for Care of Cemeteries and Monuments of Jewish Culture of the Society for Care of Monuments), Bogusław Molski (director of the Botanic Garden of the Polish Academy of Sciences), Witold Piasecki (a member of The Council for the Protection of Struggle and Martyrdom Sites), Wojciech Piróg (chairman of the Capital Building Enterprise (Stołeczne Przedsiębiorstwo Budowlane).

29 "Wreaths were laid by delegations of: chief authority of The Society of Fighters for Freedom and Democracy (Zwiqzzek Bojowników o Wolność i Demokrację, ZBoWiD), The Council for the Protection of Struggle and Martyrdom Sites, World Jewish Congress (Światowy Kongres Żydów), the capital's authorities, organisations from Jewish religious associations, academic 


\section{Studies}

did not prevent the establishment of an opposition committee to commemorate the $45^{\text {th }}$ anniversary of the Warsaw Ghetto Uprising, which nevertheless operated openly; in part it grouped the same people as the Commission for the Memory Sign. ${ }^{30}$ The citizen's committee inaugurated the Wall-Monument and the Route one day earlier. The celebrations were led by Marek Edelman, Jacek Kuroń, Zbigniew Bujak, and Janusz Onyszkiewicz, accompanied by the banners of the KPN (Konfederacja Polski Niepodległej, Confederation of Independent Poland), Solidarity, PPS (Polska Partia Socjalistyczna, Polish Socialist Party) and NZS (Niezależne Zrzeszenie Studentów, and the Independent Students' Union). Kadish was said at the Umschlagplatz. ${ }^{31}$

The Wall-Monument is free from the Polonocentric image manipulation, which cannot be said of the boulder on the Memorial Route, especially those around Rapoport's Ghetto Heroes and Martyrs' Monument. According to Hanna Szmalenberg, who coordinated the work on the monument on the former Umschlagplatz, in no way did the authorities interfere in the symbolic or substantial aspects, and merely eliminated technical obstacles, provided materials and labour, and reorganised the immediate surroundings of the emerging monument, which meant eliminating the local petrol station and recultivating the terrain. The work was carried out at a veritable udarnik tempo, and all the proposals concerning the Umschlagplatz Memory Sign were approved without delay. ${ }^{32}$ If both parts of the proposal (the Wall-Monument and the Route) were planned and realised in the same manner, it would mean that the person to decide on the inscriptions was Stanisław Jankowski. (Marek Moderau designed the granite slabs, Zbigniew Gąsior was responsible for the lettering reliefs). This hypothesis is further corroborated by the fact that in the final report of the Commission, a second leg of the efforts was planned, one that was to consist in "securing and marking the places of fighting with the Germans carried out by Poles and Jews with 'memory signs'" and "aid offered to Jews by

institutions, youth representatives" ([Polish Press Agency], "Obchody 45 rocznicy powstania w Getcie Warszawskim," Życie Warszawy, 20 April 1988, 1). A speech was given i.a. by Miles Lerman, the chairman of International Relations Committee of American Holocaust Survivors Board (Komisja Międzynarodowa Amerykańskiej Rady Ocalałych z Zagłady), underlying Polish-Jewish collectivity of suffering and calling Polish people "witnesses of Jewish misery" (cf. ibidem, p. 2).

${ }^{30}$ Stanisław Jankowski, Stanisław Krajewski and Teresa Prekerowa were members of both of the bodies. Hanna Szmalenberg was also a member of the citizen's committee. For the full body of the committee cf. "Byli naszymi braćmi," Tygodnik Mazowsze 245 (6 April 6 1988): 1.

${ }^{31}$ More on the matter, cf. "Pochylmy głowy - to ich Golgota," Tygodnik Mazowsze 247 (20 April 1988): 1.

${ }^{32}$ Szmalenberg emphasises Eleonora Bergman's, Israel Gutman's and Piotr Matywiecki's contribution to the conceptual works. Teresa Prekerowa was especially active in this respect in the Commission. 
Poles?". ${ }^{33}$ The main author of the report was none other than Jankowski 'Agaton'. The narration of the Polish-Jewish brotherhood of arms and the aid discourse was, clearly, his own initiative, which did indeed reflect popular opinion and expectations.

The monument at the former Umschlagplatz is exclusively devoted to those whom it is to commemorate. At the same time, however, it is addressed to those who wish to see and know. It is characterised by a quiet, almost abstract form and is an unusual example of identity policy, without symbolic violence against people or events. The installation contains two elements that resemble matzevahs, but is devoid of any traditional Jewish mourning symbols. Their form seems to be a result of an artistic strategy, whose effect was also the hanging of 'matzevahs' of sisal, woven by Władysław Klamerus in the 1980s. They featured gravestone symbols that refer to their Jewish models, but were substantially transformed. They could actually be called after-images. In a similar vein, Monika Krajewska said "the Umschlagplatz monument is a transposition of a very deeply understood Jewish symbol." ${ }^{34}$ In the project's documentation the word 'matzevah' always appears in question marks. The white shape that resembles matzevahs, which is what the rear walls of the Wall-Monument, is broken across and cannot be reintegrated. A black element at the front, suggestive of the top of the matzevah, crowns a void. Taking as the starting point the broken tree, which symbolised individual death, the artists carved a broken, dead forest in a semicircular syenite rock.

The words from the book of Job 16: "O earth, cover not thou my blood, and let my cry have no place" in Hebrew, Yiddish, and Polish, borrowed from the Judaic tradition, had already become the heritage of the two other monotheisms that built on it, and are also part of the lay tradition. In the context of the place where Jews were tortured and massacred, and with respect to the kind of death

${ }^{33}$ It also speaks of Gęsiówka as "a concentration camp-like prison for the Jews" which was liberated by the Home Army's (Armia Krajowa, AK) battalion 'Zośka', Muranowska Street as a place of the Jewish Military Union's (Żydowski Związek Wojskowy, ŻZW) struggles, the house at Żurawia Street 24, where meetings of the Council to Aid Jews (Rada Pomocy Żydom) 'Żegota' took place, Emanuel Ringelblum's bunker by Grójecka Street, the place where a tenement used to be, by Chłodna Street 22, where Prof. Franciszek Raszeja and Dr. Kazimierz Polak were killed by the Nazis, after they were called to the Ghetto with a pass to the ill Abe Gutnajer (cf. Gieysztor, Jankowski, Sprawozdanie z działalności Komisji Towarzystwa Opieki nad Zabytkami do spraw Znaku Pamięci Umschlagplatz..., pp. 16-18).

${ }^{34}$ Quote from: "Klamerus. Własna historia," exposition from the Studio Theatre Gallery (Galeria Studio), 20 March - 5 May 2013, http://teatrstudio.pl/o-studio/galeria-studio/. In her comment on another Szmalenberg's and Klamerus's joint work, namely Lejb Najdus's tombstone (1990), Krajewska rightly noticed (wrongly ignoring Hanna Szmalenberg's co-authorship): "A traditional symbol is also a flower, the metaphor of the tree of life. Władek simplified it on the matzevach in Warsaw Jewish Cemetery, he transformed it in accordance with his vision, he was not imitating any particular example. It shows at first sight, that it is a new matzevach into which old symbols were incorporated." (ibidem). 
that befell most victims of the Holocaust, they begin to take on the character of a topical, almost contemporary commentary to the Blut und Boden ${ }^{35}$ idea, which could also be construed as a kind of secularisation. A black strip placed on the circumference of the commemoration, in many cultures has mourning connotations. Its visual shape does not bring to mind the black stripes on tallits, which for members of the Judaic religion is a sign of mourning, after the destruction of the Temple. The Warsaw Wall-Monument is something totally different from the Western Wall in Jerusalem. In Poland the Holocaust has not been incorporated into (any) theodicy. No attempt to integrate it within (any) religious narration has even been made. ${ }^{36}$

One deals with a similar situation with the absence of other, lay sensemaking operations applied, for example, by Natan Rapoport in his design of the Ghetto Heroes and Martyrs' Monument (1948). What I mean is not only the choice of figurative convention, a sign of belief in the purposefulness and effectiveness of the presentation. This comprises much more than drawing on the inspiration from François Rude's Marseillase relief (1833) on the Paris Arc de Triomphe and borrowing from Paul Moreau-Vauthier's monument on the back of the Communards' Wall (design 1900, completed 1909), where the last fighters of the Paris Commune were executed and buried in a mass grave. It is not difficult to identify in Rapoport's choice a certain polemical reference to the reliefs on the Arch of Titus in Rome (which commemorates the destruction of the Temple and the Roman triumph over the Jewish uprising. ${ }^{37}$ What I mean

${ }^{35}$ Cf. entry "Krew i ziemia," in Rosa Sala Rose, Krytyczny słownik mitów i symboli nazi$z m u$, introduction Rafael Argullol, trans. Zuzanna Jakubowska, Agnieszka Rurarz (Warsaw: Sic!, 2006), pp. 129-135; Elżbieta Janicka, “Hortus Judeorum'. Refleksje oddechowe i pokarmowo-trawienne na marginesie pracy 'Miejsce nieparzyste',' in Inhibition, ed. Roman Dziadkiewicz, Ewa Małgorzata Tatar (Cracow: Muzeum Narodowe w Krakowie, Korporacja Ha!art, 2006), pp. 99-109.

${ }^{36}$ In the world beyond monuments, among the perpetrators and their heirs, there is a widespread theodicy of punishment, which the Jews themselves prophesied, and which befell them for killing God. In a different spirit, the efforts to incorporate the Holocaust into a religious narrative were made by theologians of Judaism. This is how Yehuda Bauer comments on the results: "From an orthodox point of view, even more so from a nonreligious point of view, theology does not yet seem to have yielded any answers to the Holocaust. Historical, sociological, psychological, and maybe even philosophical explanations have been more productive. Some might even doubt the relevance of the theological answer altogether, so far. That, indeed, is my own position. The theology of the Holocaust is fascinating, but it is a dead end" (Yehuda Bauer, Rethinking the Holocaust [New Haven and London: Yale University Press, 2001], pp. 211-212). The relevant chapter in Bauer's book, “Theology, or God the Surgeon" (pp.186-212), was written in the spirit of Claude Lanzmann's statement on the attitude of the Creator of the Universe to the Jews of Grabów, in his film Shoah.

${ }^{37}$ In his programme statement from 1948, the artist has written: "I was in fact perceiving the Jewish martyrdom during the occupation not as an isolated historical incident, but as a link in the chain of the Jews' suffering, which has gone on for two thousand years in 
above all, is something that might be problematic for the artist, that is the choice of the solid structure as a strategy of artistic action. The awareness of the risk taken expressed the question the sculptor asked one critic: "So in your opinion I should have put there an ordinary piece of rock with a hole in it and tell the public: here you are, this is Jewish heroism?"38

Szmalenberg's and Klamerus's monument departs from the notion of sculpture as a solid structure. The artists chose the concept of sculpture as a spatial composition, formulated by Katarzyna Kobro with Władysław Strzemiński's participation. The idea elaborated by the two constructivists, the divisions and proportions that have the dimension of mental operations in the first place, they emphasise the role and the importance of what is in between, which is colloquially called 'nothing. ${ }^{39}$ As they had the freedom to shape space as a raw construction material in their commemoration of the Umschlagplatz, the 'nothing' proved to be equally important as 'something'. The Umschlagplatz tends to be interpreted as a symbolic wall or railway wagon. In its largest and most important part, it is indeed made up of holes, cracks and empty space. Sketchy, virtually volatile in form, it is not a symbol of void but its materialisation. And it is the void that it offers to the audience in their experience.

At the same time it can interpreted as a treaty on divisions, their negotiated, arbitrary, purely conventional character, and as one on the transcendence and the deadly potential present there. The proportion of the vertical planes and the

the form of persecutions, oppression, inquisition and massacres of Jews. Still more clearly, as a continuation of grand military traditions [...] which were continued since the national struggles for freedom during the ancient times, through spiritual resistance, up to the ongoing struggles; I perceived the great Jewish heroism in the terrible wartime. [...] This is why the characters of the combatants from the monument are both freedom fighters from the Ghetto, Jewish past heroes, and the ones that are yet to come. This is why I was trying to make an epic work, inspired by the classical spirit" (quote from: Artur Tanikowski, "Zabytek hańby naszych wrogów, a chwały naszych umęczonych bohaterów'. Urodziny pomnika Bohaterów Getta," Cwiszn 1-2 (2013): 114 - sculptor's statement was translated from Yiddish by Anna Szyba; the quotation in the title comes from "We, Polish Jews" by Julian Tuwim). On the subject of the Monument to the Ghetto Heroes and Martyrs, whose authors are Natan Rapoport and Leon Marek Suzin cf. also James Edward Young, "The Biography of a Memorial Icon: Nathan Rapoport's Warsaw Ghetto Monument," Representations 26 (Spring 1989): 69-106; Beata Chomątowska, Stacja Muranów (Wołowiec: Czarne, 2012), pp. 101-130.

${ }^{38}$ Quote from: Chomątowska, Stacja Muranów, p. 114.

39 "A sculpture should not be a cluster of shapes, closed and tight, but should have a composition that is open to space, connecting to the space, without a boundary, which would visibly separate it from the space, thus creating an artificial body from a spatial sculpture, which is alien to the laws of space. When opening a sculpture to the space and combining the two, one can avoid a construction that would oppose the space, sculpture as a whole. A sculpture should not be a foreign body in the space, nor a centre that would forcibly usurp the rest of the space. A sculpture should create continuation of the space" (Katarzyna Kobro, Władysław Strzemiński, Kompozycja przestrzeni. Obliczenia rytmu czasoprzestrzennego [Łódź: Muzeum Sztuki w Łodzi, 1993], pp. 35-36; reprinted from 1931 edition). 
irregular gaps between them are a study of closure. This is the case particularly in elements of construction, which could be called claustrophobic due to the fact that they only allow visual contact with the outside, thus making it impossible to leave the interior. But in the first place, the Wall-Monument is a kind of frame or passe-partout for what is the key element of the commemoration, namely the very place itself. When translated into a historical detail, the point is to suggest travel through a series of 'sluices' and the labyrinth behind the building that leads to the railway wagons. Several days before completion, during the sanding of the outside wall of the adjacent building (an integral part of the monument) traces of three holes were found - one for doors and two for windows. According to Marek Edelman, it was a checkpoint, where the victims marched to the railway ramp were deprived of their last valuables. ${ }^{40}$ Although it clashed with the original plan, the artists decided to uncover the holes. On the wall's edge, they reconstructed door traces in brick. Brick stripes and granite cobblestone marked the former division of the area into zones in the basalt floor of the monument. They also preserved the original cobblestone along the building.

Szmalenberg's and Klamerus's work, apart from its connections with the thought of Kobro and Strzemiński, is also suggestive of the influence of Zofia and Oskar Hansens' concept of Form. Hanna Szmalenberg worked on a number of projects completed under Hansen. Władysław Klamerus, on the other hand, apart from his sculpture diploma, obtained a degree of specialisation at Hansens' Workshop of Visual Structures at the Warsaw Academy of Fine Arts. ${ }^{41}$ The point of departure or the frame of reference for the Wall-Monument seems to be the Monument-Path designed for the Auschwitz II-Birkenau camp in 1958 by this team, composed of: Oskar Hansen, Jerzy Jarnuszkiewicz, Julian Pałka, Edmund Kupiecki, Zofia Hansen. The spirit and letter of Hansen's thought, which dismisses emulation, manifest themselves at the former Umschlagplatz in treating as building material or a sculptor's medium space as such on the one hand and on the other what Hansen called emotional margin. ${ }^{42}$ This kind of thinking is

${ }^{40}$ Cf. Gieysztor, Jankowski, Sprawozdanie z działalności Komisji Towarzystwa Opieki nad Zabytkami do spraw Znaku Pamięci Umschlagplatz..., p. 9.

${ }^{41}$ Grzegorz Kowalski includes Szmalenberg and Klamerus in a group of Hansen's apprentices (cf. idem, "Dwie ostatnie wystawy Oskara Hansena," in Wobec Formy Otwartej Oskara Hansena. Idea - utopia - reinterpretacja, ed. Marcin Lachowski, Magdalena Linkowska, Zbigniew Sobczuk [Lublin: Towarzystwo Naukowe KUL, Lubelskie Towarzystwo Zachęty Sztuk Pięknych, Katolicki Uniwersytet Lubelski Jana Pawła II, 2009], p. 138). Hanna Szmalenberg recollects Klamerus's ante-mortem wish “to sculpture three busts of his masters. Next to Władysław Strzemiński and Katarzyna Kobro, he also included Oskar [Hansen]." Quote from: Filip Springer, Zaczyn. O Zofii i Oskarze Hansenach (Cracow-Warsaw: Wydawnictwo Karakter i Muzeum Sztuki Nowoczesnej w Warszawie, 2013), p. 204.

42 "This emotional margin was in a sense a modification of avant-garde rigour, which Oskar Hansen undertook in his architectural creations. [...] This margin of architectural structure, 
as distant as possible from the idea of representation or reconstruction. This consists in making the audience aware of phenomena without pressing home the narrative of 'been there done it'. It does take into consideration the relic, but it is devoid of fetishist attitude to it.

It is no accident that the most ruthless critic of Szmalenberg's and Klamerus's design was the architect Czesław Bielecki, ${ }^{43}$ an opponent of Hansen's ideas, who believed that the monument at the former Umschlagplatz should have the form of a cattle wagon with figures of Jews wearing armbands. There is no paper trace of Bielecki's position. But the essence of his opposition to the Wall-Monument seems identical to what he said about the Monument-Path twenty years later:

So, in my opinion the problem [...] concerns the question to what extent (and that is what Hansen touched upon aesthetically) [can one] modify the authentic, even if one intends to copy it. Hansen's objection was that the copying would mean mystifying the past, and that one would simply be reconstructing this past that one would be putting up evermore cheap watchtowers made of cheap planks. So, I am trying to make a professional remark that it is an experience, which Hansen completely ignored, because as an artist he ignored the persuasive layer, which is implicitly related to the fate of the architect. ${ }^{44}$

However, Szmalenberg and Klamerus chose architecture without persuasion. Having heard Bielecki's criticism they reinforced their position. Namely, they dropped the idea of a cattle wagon relief on the wall of the adjacent building, and the sgraffito plan of the Umschlagplatz. At this point, one saw a manifestation not only of a different level and kind of awareness, but also of a vision of human relationships. What they had in common with the Hansens was the rejection of paternalism and also of collectivism and an attachment to hierarchy. This was combined with a determined option for egalitarianism that would consider the potential of the individual, the individual differences, changes and interference as well. In Hansens' thought, the architect's proposal was to be a mere passepartout for these qualities. When they designed the passe-partout for the void

with regard to designing monuments, was actually becoming a fundamental means of expression." (Piotr Juszkiewicz, "Przestrzeń i pamięć. Projekt oświęcimskiego pomnika Oskara Hansena," in Wobec Formy Otwartej Oskara Hansena..., p. 174).

${ }^{43}$ Before 1989, he was a democratic opposition activist, in the Third Republic, a rightwing politician and publicist. As a public figure of Jewish origin, he speaks on Polish-Jewish relations and issues in the spirit of unconditional Polish patriotism.

${ }^{44}$ Czesław Bielecki's stance on the Lublin symposium "Wobec Formy Otwartej Oskara Hansena" (ibidem, p. 211). On the impulse of criticising Hansen, Bielecki did not hesitate to refer to the rhetoric of denunciation: "I, as an anticommunist, after my first internship and career in the West, was in turn sensing, that he was a type of Marxist without a party, and even Żeromski's ideas were pouring from him, was also completely non-concrete. [...] As one of the fathers of liberalism, Friedrich von Hayek, used to say: 'the idea of socialism is inherently reactionary', Hansen did not understand that" (ibidem, pp. 165-166). 
left by those murdered, Szmalenberg and Klamerus clearly bore in mind what Hansen said about designing space as a passe-partout for the all of the living: "The point is that each man should be able to develop as himself, so that he would not be subordinated." ${ }^{45}$ Hence, I believe, the decentralised form of the monument and the policy of identity it assumed. At the former Umschlagplatz, carved in white stone ${ }^{46}$ were names, from Abel to Żanna and information in Yiddish, Polish, Hebrew, and English: "Along this path of suffering and death over 300,000 Jews were driven in 1942-1943 from the Warsaw Ghetto to the gas chambers of the Nazi extermination camps."

The choice of names was inclusive. One finds here names, often identical, in their Hebrew and Yiddish versions, next to names characteristic of the culture of the Polish, Russian or German language. This formula shatters the idea of the victims as a homogenous group and it gives precedence to self-identification. So the approach to identity is one of cultural constructivism, which is a clear declaration of the intent to empower the victims. According to Szmalenberg and Klamerus, this gesture was to be a kind of 'roll-call of the victims of the Umschlagplatz. ${ }^{\prime 4}$ In the light of the impossibility to conduct a complete reconstruction of the names of those murdered (something that was done at the Paris Mémorial de la Shoah), it does necessarily remain suspended, which arouses particularly strong emotions among an audience socialised in more individualistic and horizontal cultures that the collectivist and vertical Polish culture. The highlighting of differences entails indicating the common denominator, which turned such a heterogeneous group into a homogenous one; namely the anti-Semitic violence, which not only equalised but also homogenised everyone. In this particular place one deals with German violence, well identified and described; one that is no longer threatening to the Polish heroic and martyrdom narration.

\section{b) the Monument to the Fallen and Murdered in the East}

The idea of the Monument to the Fallen and Murdered in the East was born in the opposition circles, in its national-Catholic wing, namely the Movement for Defence of Human and Civil Rights (Ruch Obrony Praw Człowieka i Obywatela, ROPCiO). "In 1989, on the initiative of Wojciech Ziembiński, Jan Olszewski, Jadwiga Zienkiewicz and members of the Independent Committee to Investigate the Katyń Massacre, the Organisation Committee to Build a Monument of Victims

${ }^{45}$ Unpublished Maryla Sitkowska's interview with Oskar Hansen, quote from: Springer, Zaczyn..., p. 237.

${ }^{46}$ It was Biała Marianna marble (material with a strong symbolic position in Polish belleslettres) to which, with the agreement and advice of Hanna Szmalenberg - granite, which is more resistant to cold, was added in the 2000s.

${ }^{47}$ Cf. Gieysztor, Jankowski, Sprawozdanie z działalności Komisji Towarzystwa Opieki nad Zabytkami do spraw Znaku Pamięci Umschlagplatz..., p. 8. 
of Soviet Aggression was established, which in 1991 became the Foundation for the Fallen and Murdered in the East." ${ }^{48}$ This milieu consistently presented a vision of the past that equated Nazism with communism and equated the fate of the victims. In his justification of the need to erect such a monument the Foundation chairman, Wojciech Ziembiński, stressed that "the two totalitarianisms that assaulted Poland in 1939, left indelible marks on our reality by mass deportations and transports of people to death camps and the Gulag." 49

The story of the monument is primarily that of attempts and efforts to locate it in a most conspicuous and thus highly symbolic place. It was meant to be a kind of symbolic advancement of facts, which before 1989 had been absent in official narrations, but held a prominent place in that of the opposition. One of the objectives was certainly to introduce a narration close to the ROPCiO circles into the mainstream.

In the agendas of the Warsaw municipal authorities, the Monument to the Fallen and Murdered in the East is remembered as a hero of a never-ending story, of a commemoration for which no place was adequately honourable.

On 17 September 1990 (the anniversary of the 1939 Soviet invasion of the Eastern parts of the Second Polish Republic) the foundation stone was consecrated in J.A. Dąbrowskiego Square and the Committee proclaimed

${ }^{48}$ Irena Grzesiuk-Olszewska, Warszawska rzeźba pomnikowa (Warsaw: Neriton, 2003), p. 190. Wojciech Ziembiński became the chairman of the Foundation's Council - during the war he was a member of Pobudka (military organisation, which was a part of Bolesław Piasecki's Confederation of the Nation (Konfederacja Narodu Bolesława Piaseckiego), the leader of the pre-war National Radical Camp (Obóz Narodowo-Radykalny, ONR) Falanga), a prisoner in a German labour camp in Karlsruhe, soldier of Polish Armed Forces in the West (Polskie Siły Zbrojne na Zachodzie), a member of the democratic opposition after the war, adversary of the round table agreements, supporter of Jan Olszewski's ruling. Leon Komornicki is still the chairman of the Foundation's Management Board - Gen. of a Polish Army division, graduate of the Malinovsky Military Armoured Forces Academy (Akademia Wojsk Pancernych im. marsz. Rodiona Malinowskiego) in Moscow (1974-1977), auditor of the Military Academy of the General Staff of the Soviet Armed Forces (Akademia Sztabu Generalnego Sit Zbrojnych ZSRR) in Moscow (1981-1984), deputy head of the Polish General Staff (Sztab Generalny Wojska Polskiego) (1992-1997), during the Poland's People Republic and during the Third Polish Republic he was a laureate of national high honours. Among people who were acknowledged under the founding act of The Monument to the Fallen and Murdered in the East in the resources of the Engineering and Building Body (Zespół ds. Inżynieryjno-Budowlanych) of Warsaw's Management for Municipal Terrains (Zarząd Terenów Publicznych) listed are also: Waldemar Strzałkowski (Foundation's secretary), Krzysztof Łypacewicz (Board's vice-chairman), Stanisław Soszyński (Board’s secretary), Władysław Wysocki (Board’s treasurer). It is interesting, that Stanisław Soszyński is also a former Warsaw chief artist who complemented the monument on the former Umschlagplatz for the high artistic level.

${ }^{49}$ Małgorzata Rutkowska, "Pomnik odkłamanej historii. Mówi Wojciech Ziembiński, przewodniczący Rady Fundacji Poległym i Pomordowanym na Wschodzie," Słowo, 15-17 September 1995. 
a honorary competition for the monument. Four designs were submitted and the winner was that by sculptor Maksymilian M. Biskupski [...]. Efforts to find a location for the monument began. In view of the limited space, the idea to locate the monument in Dąbrowskiego Square was dropped [which sounds odd, because the square is actually quite large - E.J.] Other proposed locations did not guarantee the monuments prominent placement. The second location was a little square in Książęca Street, behind the buildings of the former Central Committee of the Communist Party, and the National Museum against a high and walled in escarpment. It was there that on 17 September 1992, the relocated foundation stone was placed, with a meagre participation of the authorities and of Varsovians and school students. When Jan Olszewski's government fell, ${ }^{50}$ the monument saw another wave of problems. [...] On the $50^{\text {th }}$ anniversary of the public admission [by the Russian authorities] of the Soviet perpetration of the Katyn massacre (in April 1993), the first ready elements of the monument were shown to the public with full military ceremony [...]. In his speech, Wojciech Ziembiński appealed to the state and Warsaw authorities to find an honourable location for the monument. He pointed to Piłsudskiego Square as the right location. The previously marked place behind the National Museum did not meet the criteria of an honourable location. [...] Therefore efforts to find another location began. Among the proposals was the eastern side of Inwalidów Square or the little square at the corner of Bonifraterska and Andersa [i.e. Muranowska St. - E.J.] Some saw it fit to locate the monument in Praga, at the site of the Brotherhood of Arms monument. Ultimately, the decision was made to locate it on a square in Muranowska Street. ${ }^{51}$

The decision to locate the monument precisely in this place was taken by the Warsaw authorities in October 1994, and the Foundation was finally satisfied. ${ }^{52}$

${ }^{50}$ Right-wing government (December 1990-July 1991), whose tenure was terminated, among others, due to the scandal related to the publication of the names of collaborators of Polish secret services. The prime minister came from a neoliberal wing of the anti-communist opposition: Movement for Defence of Human and Civil Rights (Ruch Obrony Praw Człowieka i Obywatela, ROPCiO).

${ }^{51}$ Grzesiuk-Olszewska, Warszawska rzeźba pomnikowa, pp. 190-192. Out of all the proposed locations only Muranowska Street had a direct connection with the history of Jewish Warsaw.

${ }^{52}$ However, there was one discontented person in whose head a creaking noise appeared, which was something like the nearby carousel's dybbuk, commemorated in Czesław Miłosz's poem Campo di Fiori (1943): "The screeching tyres mercilessly pierce the ears. [...] All in all, this unending traffic, which is regulated only by the frequency of changing of traffic lights, gives a feeling of oppressive perpetuum mobile. It brings to mind a cranky carousel on which many confused visitors can lose their balance and in consequence fall from a narrow, uneven mound, straight under the wheels of a vehicle. [...] It would be difficult to find a worse place for Poland's greatest monument, which needs lots of space (considering the right perspective and visibility) and relative silence, which even a park's edge can provide. Why are we, the 
"The commemoration was financed by a general collection, Warsaw city's donations, and those of the army and the state." 53

The unveiling of the monument was one of the most ceremonious in the Third Polish Republic. Representatives of the highest state and local authorities were present, regardless of their political persuasions. Dignitaries of the Roman Catholic Church played an important role. The ceremony began with a pontifical mass at the Roman Catholic Polish Army Cathedral, celebrated by the Primate of Poland Józef Glemp. In his homily he established a continuity between the victims of Soviet persecution and the exiles to Siberia after the January Uprising of 1863 and all those who "in ancient times shared their exile fate and today enrich our history." ${ }^{\prime 4}$ Among those present at the mass were: Prime Minister Józef Oleksy (SLD), Senate Speaker Adam Struzik (PSL), Deputy Speaker of the Sejm Olga Krzyżanowska (UW). The participants then walked to the nearby Muranowska Street in a 'procession march' led by the chaplain of the Katyń Families ${ }^{55}$ Father Zdzisław Peszkowski. The monument was unveiled by the President of Poland Lech Wałęsa and the Chief of the General Staff General Tadeusz Wilecki, assisted by a member of an exile family and a soldier of a Lvov Home Army detachment. The Mayor of Warsaw Marcin Święcicki (UW) and the Chairman of the Warsaw Council Andrzej Szyszko ${ }^{56}$ (PC), assisted by the provincial authorities placed the

Polish people, unable in our own country to place symbols of national remembrance in areas that are thought-through, as it is done in relation to Holocaust victims" (Alda [Aida? - E.J.] Tuszko, "Pomnik pośród aut," Życie Warszawy, 3 October 1995). The author of the letter proposed placing the monument by Bohaterów Getta Street, which is in the old Nalewki, where the monument for the Battle of Monte Casino was placed in 1999.

${ }^{53}$ Cf. Place of National Remembrance (Miejsce Pamięci Narodowej) filing card no. 93 in Engineering and Building Body of Warsaw's Management for Municipal Terrains's (Zespół ds. Inżynieryjno-Budowlanych warszawskiego Zarządu Terenów Publicznych) resources.

${ }^{54}$ Małgorzata Rutkowska, "Pamięć ofiar Golgoty Wschodu," Słowo, 18 September 1995. The Uprising took place during Poland's partition between three empires: Russian, Prussian and Austro-Hungarian. It was an anti-Russian uprising of the Polish nobility that ended in its military defeat and its pauperisation due to the abolition of corvée by the tsarist regime and the deportation of many fighters to Siberia, often combined with the confiscation of property. It was an emblematic event for class conflicts that had torn Polish society apart. It was also typical of the Polish nobility's lack of realism. The exclusively positive heroic and martyrological myth of the January Uprising eventually became one of the pillars of the dominant version of Polish collective identity.

${ }^{55}$ The Katyń Families Federation (Federacja Rodzin Katyńskich) is an association of family members of the victims of the Katyn massacre.

${ }^{56}$ The anti-Soviet and often anti-Russian historical policy, with a number of elements of the anti-emancipation doxology, turned out to be the common denominator of the competing political parities: the Post-Communist left (The Democratic Left Alliance, Sojusz Lewicy Demokratycznej, SLD), Conservative-Populist (Polish Peasants' Party, Polskie Stronnictwo Ludowe, PSL), Freedom Union (Unia Wolności, UW) with its roots in the anti-communist conservative-liberal opposition or that with roots in the conservative and non-liberal anticommunist opposition (Centre Alliance, Porozumienie Centrum, PC). 


\section{Studies}

foundation stone in the base of the monument-case containing soil from Vilnius, Lviv, Katyń, Starobielsk, Vorkuta, and Siberia. ${ }^{57}$ The chairman of the Foundation for the Fallen and Murdered in the East offered the monument to the municipal authorities "recommending that the Capital of the Polish Republic provide due care for this national monument for ever." ${ }^{28}$ The monument was consecrated by the primate of Poland. The ceremony was carried out according to the full military ceremonial requirements. At the end, after the reading of the roll-call for the dead, a trumpeter played Śpij kolego $w$ ciemnym grobie ${ }^{59}$, followed by a joint singing of Boże coś Polskę ${ }^{60}$ The founding act mentions many members of the military, police, Border Guards, the Siberian Exiles Union, the Katyn Families and the scouting organisations present. ${ }^{61}$ Among those invited were representatives of Christian denominations belonging to the Polish Ecumenical Council. The chairman of the Moslem Religious Union was invited as well. Members of Judaism were not.

The meaning of this theatrum, as that of many ceremonies in the public space, may be construed as a renewal of the community and a confirmation, if not a correction, of its identity. What kind of visual representation would such a community recognise itself in? The Monument to the Fallen and Murdered in the East is an option for a figurative convention and sculpture understood as a solid structure. It shows railway sleepers and a railway wagon filled with crosses, with one cross clearly dominant.

The whole is cast from bronze. One element made conspicuous by the white shining steel of the cross is dedicated to Father Stefan Niedzielak (clandestinely murdered on 20 January 1989), who had been the parish priest of St. Karol Boromeusz Church in Powązki, where a sanctuary of the Fallen and Murdered in the East had been erected. ${ }^{62}$

On the 41 railway sleepers placed in front of the deportation wagon names of battlefields in Eastern Poland from September 1939 and places of execution on 'inhuman land' 63 were carved. The last two ties symbolise Ryazan and Kaluga,

${ }^{57}$ Cf. AŻE, "Poległym i pomordowanym na Wschodzie. W rocznicę agresji 17 września," Gazeta Wyborcza, suplement Gazeta Stołeczna, 18 September 1995.

${ }^{58}$ Founding act of monument for Fallen and Murdered in the East.

59 "Sleep, comrade, in a dark tomb, May Poland appear in your dreams" - these two lines come from a popular cavalry song "How beautiful is the war" (Jak to na wojence ładnie), written during the 1863 January Uprising.

${ }^{60}$ A Polish Catholic song expressing patriotic sentiments. It is part of the tradition of the Polish uprisings and struggle for independence. Due to the narration modelled on the Biblical narration of God's covenant with the chosen people, it is a part of the eschatological perspective of Polish Messianism.

${ }^{61}$ Ibidem.

${ }^{62}$ Place of National Remembrance's filing card no. 93.

${ }^{63}$ The Inhuman Land (1949), a book by Józef Czapski often compared with Alexander Solzhenitsyn's The Gulag Archipelago and Gustaw Herling-Grudziński's A World Apart. As 
where 'our boys' were detained in 1939 and in 1944, that is "during the second Soviet occupation". And also Rembertów, Turza and Giby, these are Polish "little Katyńs', after the Soviets marched into Poland in 1944. The last sleeper does not bear any inscription: it symbolises thousands of unknown execution and death sites. This completes the circle of the roads of martyrdom of the Polish people and the sacrifice of our soldiers. ${ }^{64}$

The Warsaw edition of Gazeta Wyborcza wrote then about the "symbolic Stations of Passion". ${ }^{65}$ Among the names carven on the railway sleepers there is Katyń, and that is why the monument is regarded as a Katyń commemoration, the most important of the several located in Warsaw. The cult of 'the fallen in the East' is closely related to the memory of Katyn at least since the 1980s. Since the late 1970s the centre of the Katyn cult was the Sanctuary of the Fallen and Murdered in the East at the St. Karol Boromeusz Roman Catholic Church at the Warsaw Powązki. ${ }^{66}$ The Muranów Monument, on the other hand, was erected as part of the Year of Katyń celebrations, proclaimed by president Lech Wałęsa, on the initiative of the Katyn Families.

A symbolic closure and at the same time a conclusion of the installation was the crowned Polish Eagle ${ }^{67}$, tied with ropes, bearing the date 17 September 1939 , welded to the railway wagon; it was given the most prominent and representative place, on the south side of the monument. The eagle is not just any eagle. Its shape is part of the emblem of the pre-war Polish Army, which was

a Polish Army officer, Czapski was imprisoned by the NKVD. Released after the SikorskiMajski Pact (1941) he was charged with locating Polish 'missing' officers, who had actually been murdered in the Katyń massacre (1940).

${ }^{64}$ Rutkowska, “Pomnik odkłamanej historii...", p. 1.

${ }^{65} \mathrm{AŻE}$, “Poległym i pomordowanym na Wschodzie...”, p. 1. The Warsaw Powązki cemetery (commonly called 'the Old Powązki') - the most prestigious necropolis in Warsaw, with an informal status of a site of national remembrance. Its lay counterpart is the civilian cemetery known as the Military Powązki.

66 "September 1, 1984 in Warsaw, Primate of Poland has blessed the Cross for the Fallen and Murdered in the East which was designed by engineer Jadwiga Zienkiewiczowa, and founded by Wojciech Ziembiński. Around the cross, on the walls of Church of St. Charles Borromeo in Powązki, almost two thousands granite tablets with the names of victims were embedded" (MR [Małgorzata Rutkowska], "Poległym i Pomordowanym na Wschodzie. 17 września - odsłonięcie i poświęcenie pomnika," Słowo, 13 September 1995, 7). Cf. also Alexander Etkind, Rory Finnin, Uilleam Blacker, Julie Fedor, Simon Lewis, Maria Mälksoo, Matilda Mroz, Remembering Katyn (Cambridge: Polity Press, 2012), p. 21.

${ }^{67}$ That is a crown with a cross on top. Apart from early antecedents, the crown was not part of the Polish national emblem throughout the Peoples' Republic of Poland (1945-1989), which was meant to signify a democratic and egalitarian character of the postwar system. The absence of the crown in the national emblem was often interepreted as a symbol of the lack of continuity of Poland's national existence. The Polish state that emerged after 1989 - with the crowned eagle as its emblem - was branded the Third Polish Republic, which was a gesture signifying the continuity of the tradition of the Second Polish Republic (i.e. before World War II), and thus cancel out the period after 1945. 
reproduced in full on the monument. Therefore the railway wagon symbolises the male military community. This enables us to understand why among the crosses there are rifles, a helmet or a military side cap. "The Polish national culture is predominantly a male culture. Its image is dominated by homoerotic relationships, the bonds of male brotherhood and friendship. Among the ideal models of this type of relationship, sung in different messages, together with school and university textbooks, there are: ${ }^{68}$ knights' regiments, boy scouts' troops, military organisations either clandestine or operating overtly. At the same time the monument is meant to symbolise the fate of civilian citizens of pre-war Poland. The Polish Army was therefore treated here as the supreme emanation of Polish statehood and pars pro toto of all 'victims of Soviet aggression' of Poland.

The artist's decision may be understood in historical terms that come from the era that is the subject of commemoration. Militarisation as an important feature of the Polish majority culture in the Second Polish Republic (1918-1939) was raised by Maria Janion. In her analysis of the phenomenon, which I would call the collectivist turn of Polish romanticism, Janion stresses that already in the $19^{\text {th }}$ century "Tyrtaeus had become the model of the poet, the soldier, and the model of a man." ${ }^{69}$ The military became the model of community. The same order perpetuated and reinforced the opinion of the supremacy of what is military over what is civilian. "The sanctity of the Polish soldier became the foundation of the national code." ${ }^{\prime 70}$ On the other hand, in pre-war Poland "the deeply anticivilian and romantic orientation of social consciousness" went hand-in-hand with the militarisation of the state. "The state was undergoing militarisation, according to the rhythm of dictatorships in Central and Eastern Europe. This militarisation encompassed various areas of ideological life and the reaction against it often took on the character of protest against state totalitarianism." ${ }^{71}$ Józef Wittlin ${ }^{72}$ saw the militarised state order as one that cannot be reconciled with the sovereignty of the individual conscious and responsible for its choices. ${ }^{73}$

${ }^{68}$ Maria Janion, “Polonia powielona," in eadem, Niesamowita Słowiańszczyzna. Fantazmaty literatury (Cracow: Wydawnictwo Literackie, 2006), p. 267.

${ }^{69}$ Maria Janion, "Wojna i forma," in eadem, Płacz generała. Eseje o wojnie (Warsaw: Sic!, 1998), p. 25.

${ }^{70}$ Ibidem, pp. 38-39.

${ }^{71}$ Ibidem, p. 30.

${ }^{72}$ Józef Wittlin (1896-1976) - poet, prose writer, essayist, and translator. Wittlin was baptised and considered a non-Jewish writer. At the same time he always spoke of his connection to the Jewish world. In Psalm, he introduced himself as "I, Józef Wittlin, of the generation of Judah" (cf. Eugenia Prokop-Janiec, Józef Wittlin, http://www.yivoencyclopedia.org/article. aspx/Wittlin_Jozef, access in August 2017).

73 "One can notice a significant decrease in the worth of human beings, both intellectual, and generally in regard to life: minds, characters, likings and passion are being put in barracks. This is why I greatly value personal morality and have high hopes for the development 
Meanwhile, Zofia Kossak-Szczucka, ${ }^{74}$ responding to the survey Literatura $a$ żołnierz [Literature and the soldier] wrote with an apologetic intention: "In Poland soldierliness is a tribal feature."75

Since we deal with a collectivist-vertical ethos of a military homo-social community, what arises is the question of subordinated and oppressed groups: women, children, and minorities. (This does not mean that in practice mensoldiers are not the victims of the system as well. However, in the sphere of cultural representation they are its undoubted beneficiaries ${ }^{76}$ ). The first part of the reply about the dominated may be found at the boulder-obelisk of 2011, added to the monument as a kind of footnote on the initiative of the Siberian Exiles Union. I quote the inscription in full - paradoxically because of its typical character, in order not to be accused of being biased or because of the ideological character of this argument. I believe that bias and ideological character are here the features of the object of the description and not of the description of the object.

"To you, human angels, without whom the blue of the sky would not be blue..." /Maksymilian Biskupski - the artist. /Passerby! / As you stand at the Monument to the Fallen and Murdered in the East in the years 19391955 [sic], pay homage to our Polish mothers, who, deported to the 'inhuman land' and persecuted by the Soviet regime, compelled to forced labour, doomed to starvation, exposure and disease, saved our children's lives and our dignity of being Polish and human so that we could also forgive. May the good Lord reward them in Heaven, and deliver us from

of morality of every single person” (Józef Wittlin, “Mały komentarz do 'Soli ziemi,'” Wiadomości Literackie 6 [1936], quote from: Janion, "Wojna i forma”, p. 31).

${ }^{74}$ Zofia Kossak-Szczucka (1889-1968) - a popular novelist, whose novels are an expression of Polish integral nationalism and integrist Catholicism. During the German occupation, a member of the anti-Nazi underground. Faced with the Holocaust, She kept all her anti-Semitic views. At the same time, guided by collective narcissism, the care for the good name and the salvation of the soul of the Polish nation, she called for non-aggression toward the Jews. She helped the Jews personally, but at the same opposed the institutionalisation of aid operations, including its systematic financing from abroad (funds from the British, American and Palestinian Jews, channeled to Poland via the Polish Underground State). Cf. Carla Tonini, Il tempo dell'odio e il tempo della cura. Storia di Zofia Kossak, la polacca antisemita che salvò migliaia di ebrei, Torino: Silvio Zamorani editore, 2005.

${ }^{75}$ Janion, "Wojna i forma", p. 32. A survey among writers recorded by Polska Zbrojna w $1938 \mathrm{r}$.

76 "In particular, the dominant agent has the power to impose his own vision of himself as objective and collective (the limiting case being represented by equestrian statues or official portraits), to make other people abdicate their generic capacity to objectify, as in love or belief, and he thus constitutes himself as an absolute subject, with no exterior, fully justified in existing as he exists." (Pierre Bourdieu, Masculine Domination, trans. Richard Nice [Redwood City: Stanford University Press, 2001], pp. 68-69). 
forgetfulness. Siberian Exiles, Warsaw Branch - 26 May 2011 A.D. on the $71^{\text {st }}$ anniversary of the first wave of deportations.

The date of the placement of the stone is Mother's Day in Poland. The implicit presuppositions of this kind of statement are among the best studied on the grounds of discourse analysis and critique of culture. They have been articulated a number of times; ${ }^{77}$ to repeat after Maria Janion reading diary:

The authors of the anthology Nationalisms and Sexualities claim that in cultures with a homo-social dominant, there appears a certain regularity, namely a particular attitude of the woman as a Mother. She is totally sanctified. ${ }^{78}$ Mother is a "figure of perfect femininity, phantasmatic femininity which protects man-man relations and male history." Men's brotherhood idealises maternity and tries to exclude "all non-productive discourse on sexuality from the national discourse." It is to be unequivocally heterosexual and procreation-oriented.

This requires a woman-mother. It is she who guarantees the national heterosexual community, its decency and customs and political correctness. [...] She is Mother-Poland and Mother-Fatherland. The dominant Polish 'public narration' determines very clear roles of Polish men and Polish women, and the patron of the Polish people is a truly ideal mother - Mother of God. ${ }^{79}$

${ }^{77}$ Classical in this field are: George Lachmann Mosse, Nationalism and Sexuality: Respectability and Abnormal Sexuality in Modern Europe (New York: Howard Fertig, 1985); idem, Nationalism and Sexuality. Middle Class Morality and Sexual Norms in Modern Europe (Madison: The University of Wisconsin Press, 1985); Nira Yuval-Davis, Gender and Nation (London: University of East London, 1998).

${ }^{78}$ In Polish culture, the angelic status of the figure of the Polish 'mother hen', a Polish mother, is a part of socio-cultural obviousness that is so deep, that it sometimes is treated as an objective description of reality. For example, a prime minister of Poland does not risk of being embarrassed, by using as a political argument a statement that "Polish fathers are not angels", meaning: as opposed to mothers (cf. Agnieszka Graff, "Czekając na anioły," Gazeta Wyborcza, supplement Wysokie Obcasy, 9 September 2013, 9). Prime minister Donald Tusk has justified in this way the refusal to elongate paternity leave.

${ }^{79}$ Janion, "Polonia powielona", pp. 272-273. Internal quotations in the first paragraph from: Andrew Parker, Mary Russo, Doris Sommer, and Patricia Yaeger, "Introduction," in Nationalisms and Sexualities, ed. Andrew Parker, Mary Russo, Doris Sommer, and Patricia Yaegar (New York: Routledge, 1992), p. 6. In the second paragraph, the author refers to a case study: Elżbieta Ostrowska, "Matki Polki i ich synowie. Kilka uwag o genezie obrazów kobiecości i męskości w kulturze polskiej," in Gender. Konteksty, ed. Małgorzata Radkiewicz (Cracow: Rabid, 2004), pp. 215-252. Further in Janion's text it is stated: “One should, however, remember that on the other pole of the homo-social continuum there is a permanently threatening homoeroticism and homosexuality. Patriotism degenerating into nationalism in particular, cannot be free from what is considered as a great threat. Nationalism, therefore, intensifies homophobic moods, because, spectacularly based on a homo-social male community, can be especially vulnerable to homoerotic inclinations." (eadem, "Polonia powielona”, p. 273). 
Children-Poles-Siberian-Exiles speak about Polish-Mothers-Siberian Exiles. The gaze of the child is here assigned all the attributes and privileges of the male power of gaze. ${ }^{80}$ Female children have been deprived of their right to judge and of their voice. It is not up to them to decide and express their own opinion. As Polish Mothers in spe, and in the meantime as Polish virgins, that is the patriotic variety of a sexual object, will themselves soon be judged. In Pierre Bourdieu's words, who studied the treatment of women through the prism of femininity not as a personal status, here one deals with an understanding of the woman as a vehicle of (re)production of the male biological and symbolic capital. ${ }^{81} \mathrm{In}$ the patriarchal system the stake of the game is the preservation, expansion and transmission of the biological and symbolic capital of man, in this case of the Pole.

The second-boulder-footnote on the horizontal plane of the monument also features the figure of the father. The adjacent obelisk commemorates the visit of the head of the Roman Catholic Church, Pope John Paul II, who prayed here for the "victims of the Soviet aggression" on 11 June 1999, after he had prayed for 'Jews' at the Umschlagplatz. ${ }^{82}$ Next to Polish-Mothers-Siberian Exile there appears then, fleetingly as appropriate for a patriarch, the Holy Father, a Pole. In other words, the entire family. Patriarchal, hierarchical, heterosexual and asexual at the same time, but primarily Polish, if not a Katyń family at the same time. I do not refer here to actual persons, relatives of the victims of the Katyn massacre nor to their organisation, the Federation of Katyn Families. I am interested in the mode of self-representation of a memory community that is broader than the circle of victims. An enormous monument in a prominent place in the heart of the Polish capital city was erected with regard to the status assigned to the Katyn massacre and to the Soviet deportation in the History of Poland. The question of the mode of representation of a memory community is thus a question of how the legitimate collective subject of memory of the history of Poland is imagined, if not the subject of Polish history tout court.

This subject is presented as a political community, but also as a family community. This phenomenon is characteristic of the Polish dominant culture,

80 "Thus, the gaze is not a simple universal and abstract power to objectify, as Sartre maintained: it is a symbolic power whose efficacy depends on the relative position of the perceiver and the perceived and on the degree to which the schemes of perception and appreciation that are brought into play are known and recognized by the person to whom they are applied" (Bourdieu, Masculine domination, p. 65). Further Bourdieu describes the way in which masculine domination creates a woman as an object, a commodity on the market of symbolic goods, "whose being (esse) is a being-perceived (percipi)" (ibidem, p. 66).

${ }^{81}$ Cf. ibidem, pp. 56-57.

${ }^{82}$ The object cannot be found in the Management for Municipal Terrains's files. It is therefore a trace of constructional self-will, yet undoubtedly tolerated both by the Management for Municipal Terrains, and the Sybirak Association (Zwiq̨zek Sybiraków) and the Fallen and Murdered in the East. 
where it is customary to speak about society in terms of the nation, and of the nation in family terms. The strong position of the family imaginarium corresponds to the deficit of civil imagination, not only in the sphere of politics of memory and identity. Defining the nation in terms of blood bonds not only blocks any rational debate, but also makes it difficult to articulate interests and vindicate rights (e.g. of women or sexual minorities ${ }^{83}$ ). It also disciplines all those who do not belong to this family. The anti-emancipatory, anti-egalitarian, antidemocratic and exclusive family imaginarium is so legitimate that it is a source of legitimacy itself. As such it also provides the language to those who are not immediately associated with Catholic ethno-nationalism or integral nationalism of the National Democracy, ${ }^{84}$ such as the Polish prime minister Donald Tusk, who during the celebration of the seventh anniversary of the Katyń massacre could not find any other formula than "We, all of us, Poles, are one large Katyń family". ${ }^{85}$

Therefore the important question is about the situation of minorities. On closer inspection, the Monument to the Fallen and Murdered in the East features, among crosses on the railway wagon, the Moslem symbol with a fivepointed star and a crescent, several Orthodox crosses and a matzevah with the Star of David. ${ }^{86}$ Here one has a hierarchy, which does not even try to give

${ }^{83} \mathrm{Cf}$. case study of the phenomenon on examples from the first decade of 2000s: Agnieszka Graff, Rykoszetem. Rzecz o płci, seksualności i narodzie (Warsaw: W.A.B., 2008). Historian of an idea sees it as increasing "collectivist-despotic tendencies": "Wide acceptance of an opinion that collectivity, defined one way or another, has the right to extensive prescriptive control over the entity, which comprises essentially everything, became an especially widespread form of ethical anti-liberalism in Poland. Defenders of women's rights and national minorities may say a lot about it [...]" (Andrzej Walicki, "O polskiej rzeczywistości moralnej," in idem, Od projektu komunistycznego do neoliberalnej utopii [Cracow: Universitas, Polska Akademia Nauk, 2013], p. 277).

${ }^{84}$ National Democracy (Narodowa Demokracja), a political party that determined the shape of the political scene in the Second Polish Republic (1918-1939). A symbol of Polish chauvinism.

${ }^{85}$ Donald Tusk's speech given at Katyń war cemetery on April 7 2010, https://www.premier.gov.pl/wydarzenia/aktualnosci/premier-tusk-jedno-slowo-prawdy-moze-pociagnacdwa-wielkie-narody.html, access 1 September 2013.

${ }^{86}$ The idea will be reflected in the solution applied five years later at the Polish war cemetery in Katyń near Smolensk (Russia) and at the Victims of Totalitarianism Cemetery in Piatykhatky near Kharkiv (Ukraine), where the symbols of three monotheistic religions (two Christian) and four denominations shall stand next to each other: Roman Catholicism, Eastern Orthodoxy, Judaism and Islam. Initially, they were placed in a manner symbolising equality in diversity, but the prevalence of Catholic symbols in Polish sections of both cemeteries is undivided. In Katyń, crosses lying on the ground mark places of burial; apart from a cross in the altar, there is also a cross unveiled in 1989 by Cardinal Józef Glemp, the Primate of Poland. A plethora of standing Catholic and Eastern Orthodox crosses dominates the landscape of the cemetery in Piatykhatky. As for the Polish war cemetery in Miednoje, I only have its descriptions and photographic documentation too scarce to draw any meaningful conclusions on this 
a semblance of equality. Orthodox (and Greek-Catholic?) crosses vanish among the dominating Catholic (and most assuredly Protestant) crosses. It is a different story with non-Christian religions. The Moslem emblem was delegated to the north-western corner of the railway wagon. The matzevah found itself on the eagle's axis on the opposite end of the monument. The symbols are turned 'back to back'. The eagle on the southern side is in full light for most of the day. The matzevah is on the northern side, where the sun does not reach it. The opposing location on the axis repeats the pattern ecclesia versus Synagogue. ${ }^{87}$ (Atheists are not represented).

The inclusive intention is thus accompanied by gestures of hierarchical position, which are in fact exclusive gestures or at least they have an exclusive potential. By the Monument to the Fallen and Murdered in the East one could conduct civic education lessons on the tensions and resistance among the majority to the idea of inclusion. Another theme is 'confessionalisation', i.e. religious definition and expression of identity (a growing phenomenon in most countries of the Eastern bloc, as well as in the former Soviet republics, including Russia itself). The third theme: the model of the community as a set of groups perceived not only in terms of national groups but also in terms of religious groups. Each stage of the reflection, individually and all together could be accompanied by the question about the individual and the protection of his or her rights against the claims of all kinds of reference groups: confessional, minority national, and majority national. In other words, the question about liberal democracy and its relations with non-liberal and nondemocratic identity orders. $^{88}$

subject. In Katyń, also the hierarchy of the dominant group was reconstructed, by burying generals in individual graves, each with his own cross.

87 "That blacks are the antithesis of the mirage of whiteness, the ideal of European aesthetic values, strikes [...] as an extension of some 'real', perceived difference to which the qualities of 'good' and 'bad' have been erroneously applied. But the very concept of colour is a quality of Otherness, not of reality. For not only are blacks black in this amorphous world of projection, so too are Jews [...]The image of the Jew as the black was not merely the product of the racist biology of the late nineteenth century [...] For the association of the Jew with blackness is as old as Christian tradition. Medieval iconography always juxtaposed the black image of the 'synagogue', of the 'Old Law', with the white of the Church (cf. Paul Weber, Geistliches Schauspiel und krirchliche Kunst in ihrem Verhältniss erläutert an einer Ikonographie der Kirche und Synagogue (Stuttgart: Neff, 1894), and Paul Hildenfinger, "La figure de la synagogue dans l'art du moyen âge", Revue des Études Juives 47 (1903): 187-196). The association was an artefact of the Christian perception of the Jew, which was simply incorporated into the rhetoric of race [...] In the eyes of the non-Jew who defined them in Western society, the Jews became the blacks" (Sander L. Gilman, "Introduction: What Are Stereotypes and Why Use Texts to Study Them?," in idem, Difference and Pathology: Stereotypes of Sexuality, Race and Madness [IthacaLondon: Cornell University Press, 1990], pp. 30, 31).

${ }^{88}$ It would be intellectually unfair not to mention Andrzej Walicki's point of view in the conflict between the idea of nation and the idea of democracy: "[F]or there are national ide- 


\section{$242 \quad$ Studies}

Meanwhile, the Monument to the Fallen and Murdered in the East does not serve cognitive practices but confessional ones, and, so far, only of the majority group. One part of the monument is a plaque with a cross that resembles the military cross of Virtuti Militari ${ }^{89}$ with the inscription: "To the fallen [and] murdered in the East/ to the victims of the Soviet aggression/17 September 1939; the Nation, 17 September 1995". The visitors burn candles and add religious emblems such as flower crosses or the figure of the Crucified Jesus. There are also others, who lay flowers separately, at the monument of the officers of the Polish Army murdered at Katyn of Jewish origin, that is the so called 'WM's (Poles members of the mosaic religion [wyznania mojżeszowego]. The monument is located in Warsaw at the Jewish Cemetery in Okopowa Street, behind a wall. On the other hand, the Monument to the Fallen and Murdered in the East is described and functions in the collective consciousness as the railway wagon with crosses. This image is reinforced by postcards, tourist guides, ${ }^{90}$ web sites, ${ }^{91}$ children's

ologies that do not collide with democratic and liberal values, that enrich liberal democracy with a historical-communal dimension without any attempts to regress to suffocating forms of exclusive, mono-identity tribal community. I call one of them [...] 'liberal nationalism'. It rejects both 'constructivism' (the theory of nation as an artificial 'construct' and a freely chosen community) and 'essentialism', rendering the individual a slave of the above-individual represented by some more or less self-proclaimed elite. It construes nation as a community above the local ones, as widely as possible, thus, inclusive, individualised and pluralistic; it defines cultural community communicatively as a dialogue and not as an obligatory, top-downcontrolled 'identity'” (Andrzej Walicki, “Czy idea narodu musi być monopolem prawicy?," in idem, Od projektu komunistycznego do neoliberalnej utopii [Cracow: Universitas, 2013], pp. 212-213). One could ask if liberal democracy indeed needs a 'nationalistic' correction, or maybe it is the other way round: liberal-democratic discipline is crucial to tame nationalism, both literally and figuratively.

${ }^{89}$ The War Order of Virtuti Militari (Latin: For Military Virtue, Polish: Order Wojenny Virtuti Militari) is Poland's highest military decoration for heroism and courage in the face of the enemy at war," https://en.wikipedia.org/wiki/Virtuti_Militari, access in August 2017.

90 "The Monument to the Fallen and Murdered in the East is the most horrifying monument in Warsaw. A pile of crosses on a huge flat wagon symbolises Poles deported deep into the USSR" (Agnieszka Kowalska, Łukasz Kamiński, “Wagon z krzyżami. Ul. Muranowska," in eidem, Zrób to w Warszawie! Alternatywny przewodnik „,Gazety Co Jest Grane” [Warsaw: Agora, 2008], p. 58).

91 "The monument was erected in honour of Poles killed and murdered in the East, in particular those deported to labour camps in Siberia [...] and victims of the Katyń massacre [...] The statue shows a pile of [crosses] on a railway flat wagon, which is set on tracks. Each railway sleeper displays the names of places from which Polish citizens were deported for use as slave labour in the USSR, and the names of the camps, collective farms, exile villages and various outposts of the gulag that were their destinations, including the mass murder sites used by the Soviet NKVD [...] Pope John Paul II prayed here during his seventh Polish pilgrimage in 1999. In 2006, during his pilgrimage to Poland, Pope Benedict XVI's pope mobile was also taken past this monument...," https://en.wikipedia.org/wiki/Monument_to_the_Fallen_ and_Murdered_in_the_East. 
drawings, ${ }^{92}$ as well as one of the popular series of paintings by Jerzy Duda-Gracz, Golgota Jasnogórska. ${ }^{93}$

The colloquial term for the object of commemoration, the Golgotha of the East (Golgota Wschodu), is another exclusion factor. The topics of the Golgotha, i.e. of the Crucifixion, function in religious and lay images of Jewish martyrdom, but refer to the Holocaust. ${ }^{94}$ In the first place it is not given a prominent place in contexts, which guarantees that it will be almost anti-Semitically recaptured and appropriated. Meanwhile, the same context is present in Poland, where many believe that contemporary Jews are responsible for the crucifixion of Jesus, and thus there is the resultant belief in ritual murder, while the mainstream intellectual can, without risking being compromised, publish a book Kto zabit Jezusa? (Who killed Jesus?) and repeat in it the full set of anti-Semitic Christian clichés, whose criminal potential has even been noticed by the Magisterium of the Roman Catholic Church (forty years after the Holocaust).

The masculinisation, militarisation, 'ethnicisation', and 'confessionalisation' of the community, reflected in its visual representation on the axis of Stawki Street, are undoubtedly adequate in the reality of the commemorated era. One has here a reproduction of domination/subordination structures and their accompanying images, characteristic of the society and the majority culture of the Second Polish Republic. The fact is that the patterns, in force there and then, prevent the Monument to the Fallen and Murdered in the East from performing the integration, inclusive function here and now.

\section{Pacification procedures in action}

The topographic location of the Monument to the Fallen and Murdered in the East is an example of both concealment and substitution as well as polemic surrounding. Concealment and substitution manifest themselves with reference

${ }^{92}$ I saw such pictures at my friends' and at the art competition for children organised by the POLIN Museum of the History of Polish Jews in 2009.

93 "Christ lies down on the cross voluntarily, 'nailed' to it with human pain and martyrdom of victims who suffered and died in prisons and labour camps for God and Fatherland. Their memory symbolises Polish Way to our Resurrection. The wagon, a monument to the Fallen and Murdered in the East, and the car, a 'monument' to the martyrdom of Priest Popiełuszko" ("Stacja XI - Krzyżowanie," in Jerzy Duda-Gracz, Golgota Jasnogórska, introduction by Jan Golonka, poems by Ernest Bryll (Częstochowa: Wydawnictwo Zakonu Paulinów “Paulinianum”, 2001). Jasna Góra is a Roman Catholic shrine of the so-called Our Lady of Częstochowa, who bears the title 'Queen of Poland'. In Jerzy Duda-Gracz the Golgotha topos refers therefore to the collective corpus of Poles-Catholics, which is at the same time the body of Christ. This symbolic construct bears a specific name: 'Poland - the Christ of the Nations'.

${ }^{94}$ For example, in the works by Emanuel Ringelblum, Calel Perechodnik, Ignatz Maybaum, Franklin Littell, Zinovii Tolkatchev, Marc Chagall, Adina Blady-Szwajger, Helena Merenholc, Adolf Rudnicki, Ludwik Hering, Henryk Grynberg, and Jan Tomasz Gross, to name but a few. 


\section{Studies}

to the place where the installation was placed. Polemic surrounding, on the other hand, refers to the Umschlagplatz that is the so-called Jewish monument, which by virtue of cultural inertia is a kind of challenge or a call for symbolic rivalry.

\section{a) The Mother-Siberian Exile Square}

The Monument to the Fallen and Murdered in the East is located where the old Muranowska Street merged into Muranowski Square, in the immediate vicinity of Nalewki Street. These are emblematic places of the Jewish Warsaw: an iconic square and the end of an iconic street. To call this square that of the Mother-Siberian Exile is an example of replacement. ${ }^{95}$ The substitution of the name-symbol is accompanied by appropriation of the area and only of the area, because the name-symbol itself, protected by concealment, remains untouched..$^{96}$ Concealment and substitution are for the bold. The place gained international fame due to testimonies of Jan Karski and Symcha Rotem ("Kazik") in Claude Lanzmann's film. In the early days of the Warsaw Ghetto Uprising, Muranowska Street and Muranowski Square, on the Nalewki side were one of the three main resistance points. It was here that two flags (which later became legendary) hung white and red and white and blue. It was here that the famed tunnel under Bonifraterska Street was located. This is also where the Jewish Fighting Union (Heb. Ha-Irgun Ha-Cvai Ha-Yehudi) fought, under the command of Paweł Frenkel and Leon Rodal; and an armed organisation, independent of the

95 “The name 'Mother Sybiraczka Square' (Skwer Matki Sybiraczki) was given pursuant to resolution no. XXXVII/1153/2008 of the City Council of the Capital City of Warsaw of July 10, 2008 concerning the naming of the square in Śródmieście District of the Capital City of Warsaw (Mazowieckie province's Official Journal, no. 141 of August 18, 2008, item 5001). Prior to the resolution, the object did not have its own name and was a part of Muranowska Street. It was the Sybirak Association who issued a request to name the square 'Mother Sybiraczka' to the City Council of the Capital City of Warsaw in 2005 and 2007 [...] After discussing the matter with the applicants, members of the Council responded positively to the proposal by giving this name to the place between Muranowska Street and the Monument to the Fallen and Murdered in the East. Members of the Śródmieście District Council also positively responded to the Sybiraks' request..." (private e-mail of June 12, 2014, from Simona Kowalewska, Vice Chancellor of the Heritage and International Cooperation Division of the Bureau of Culture at the Warsaw City Hall).

96 "There are two basic types of the art of 'disremembrance'. The first could be called a simple oblivion, and it is when collective memory of some ideas, organisations and people who created them almost entirely disappears. They are all displaced to the so-called archives of history (or to "the dumpster of history", to recall one of polemical phrases popular in the past); they are kept in collections gathered by scholars; they engage eccentrics and anchorites. The second type, a diverting oblivion, is initiated by the transfer of names, slogans and terms and followed by a displacement of their original content. Names and slogans are then given a second life full of influence and fame; ideas behind them, however, are concealed" (Andrzej Mencwel, "Koniec marzeń," in Sens uczestnictwa. Wokół idei Jana Strzeleckiego, ed. Andrzej Siciński [Warsaw: Wydawnictwo IFiS PAN, 1991], pp. 22-23). 
Jewish Fighting Organisation, established by Brit Trumpeldor (Betar), a youth umbrella organisation of Włodzimierz Jabotinsky's Zionists-revisionists. ${ }^{97}$

In the early 2000s, in the light of concealment and substitution amends were initiated. On request of the Jerusalem Begin Centre, the custodian of Zionistsrevisionists, including Betar, near the Mother-Siberian Exile Square a plaque with the following information was placed:

On 19-22 and 27-28 April 1943, one of the major skirmishes of the Warsaw Ghetto Uprising was fought, a skirmish initiated by the Jewish resistance movement. The Jewish fighters, led by Paweł Frenkel, the commander of the Jewish Fighting Union (JFU), for several days fended off German assaults. Jewish and Polish flags fluttering over the Muranowski Square and visible from a number of spots in Warsaw were for its citizens a symbol of the battle against the German occupier. ${ }^{98}$

The inscription was a product of negotiations between the Begin Centre and the Council for the Protection of Struggle and Martyrdom Sites. ${ }^{99}$ This is a classical instance of statement based on concealment. The inscription in three languages (Polish, English, and Hebrew), creates an impression of Polish-Jewish community and concord, if not reciprocity. What it fails to mention is the actual common part of this history, that is the material exploitation of JFU soldiers by the Poles, and furthermore that all Betar members died after they had left the ghetto going to the 'Aryan' side, most of them having been denounced. On the one hand, one could use the traditional formula: 'not bad as for Poland'. Only three sentences referred to so-called Polish issues. Moreover, the plaque is devoid of the false but popular (both in communist and contemporary Poland) information about Poles fighting in the ranks of the JFU or the always handy slogan of Polish-

${ }^{97}$ Cf. Dariusz Libionka, Laurence Weinbaum, Bohaterowie, hochsztaplerzy, opisywacze. Wokół Żydowskiego Zwiq̨zku Wojskowego (Warsaw: Stowarzyszenie Centrum Badań nad Zagładą Żydów, 2011), especially from page 451.

${ }^{98}$ The second date, 27-28 April 1943, comes from legends about the JFU.

${ }^{99}$ The Council for the Protection of Struggle and Martyrdom Sites was represented by its secretary Andrzej Przewoźnik, and Menachem Begin, the Heritage Centre was represented by Moshe Arens, former Defence Minister of Israel (cf. the letter of April 1, 2008 from the Council for the Protection of Struggle and Martyrdom Sites to the Civic Dialogue and Initiatives Office at the Chancellery of the President of the Republic of Poland available in the archives of the Municipal Roads Authority at the Municipal Information System Department; cf. also the private e-mail of June 6, 2014 from Michael Sobelman, the spokesperson for Israeli embassy in Poland. Moshe Arens wrote a monograph on the Jewish Fighting Union: Flags over the Warsaw Ghetto. The Untold Story of the Warsaw Ghetto Uprising (Jerusalem, New York: Gefen Publishing House, 2011). In Libionka and Weinbaum's opinion: “[Arens's] work is formidable, but it cannot be considered a scientific publication. Besides, his approach to the topic and the use of relevant literature may astonish readers well-versed on the subject" (Libionka, Weinbaum, Bohaterowie, hochsztaplerzy, opisywacze..., p. 18; cf. ibidem, the critical analysis of Arsen's work on pages enumerated in the index under "Arens"). 
Jewish brotherhood at arms. On the other, the content of the remembrance does not reveal any story that would be an alternative to the dominant narrative.

The plaque is situated out of the way, on the facade of a house built on ghetto debris, above the street level. It is made of transparent plexiglass and obscured by trees, so it cannot be seen. From the formal point of view, concealment and substitution (of symbols) and the appropriation of the place had been reduced. Simultaneously, it changed nothing in the popular perception. One could wonder how the relation of concealment and substitution changed into the relation of polemic surrounding ex post. It would consist in using the Monument to the Fallen and Murdered in the East to surround the tragic story of JFU fighters, as well as of the other ghetto fighters (from the Jewish Fighting Organisation and those with no affiliation). It is tragic because of what the Polish pro-independence underground, the 'blue' police and Polish civilians did or failed to do.

\section{The Muranów axis}

The main surroundings are focused not so much on the place and its history as is revealed in the correspondence of the two monuments located on the Stawki Street axis. ${ }^{100}$ The monument of the deportations of the Jews to their death is characterised by a discreet location, among a line of buildings and structures on the even-numbered side of the street. It touches the wall of the adjacent building. The Monument to the Fallen and Murdered in the East has a central location, on an elevated plane, in the middle of an important transport hub. The spatial arrangement applied here refers to the years-long architectural and urban planning practice of a symbolic character. Namely, the lay rule of urban planning that reflects the traditional relation of domination/subordination characteristic of the Christian world.

A synagogue was usually built in the centre of a town or close to it, but at a certain distance from the local church, being, as a rule, separated from the church by the market place. It was also a rule that a synagogue building must not be bigger and higher than the local church. [...]The axis connecting the church and the synagogue maps out the main religious opposition between the Jews and the Roman Catholic Poles. The latter perceived the Jews through the religious categories interpreted and imposed by the church: as the enemies and detractors of Christianity, those who had rejected and crucified Jesus. The opposite location of the religious buildings of the two religions, the fact that the synagogue was 'on the other

${ }^{100}$ Apart from three direct surroundings of the monument on the former Umschlagplatz that draw on the Kotwica (anchor) symbol of the Fighting Poland (Polska Walczqca) and the events of the Warsaw Uprising. More on the subject in Elżbieta Janicka, Festung Warschau, introduction Bożena Keff (Warsaw: Krytyka Polityczna, 2011), pp. 73-75, 164-171. 
side' of the Polish religious centre, was the material embodiment of the Jews' situation encoded in the urban landscape. ${ }^{101}$

This kind of settlement policy was in fact a policy of identity. It reflected the logic of group affirmation by contrasting it with the anti-group. ${ }^{102}$ Joanna Tokarska-Bakir says that "difference was perceived in terms of simple opposition". ${ }^{103}$ One should say it more precisely that the opposition human/inhuman did not create a simple symmetry, where two worlds would have functioned on equivalent terms, but it was a world versus antiworld relationship. ${ }^{104}$ The human/inhuman relation, characteristic of the us/ them qualification was replaced by the human/anti-human relation. In the Christian imaginarium Judaism ceased to be a passive reversal, but became an active opposition. ${ }^{105}$ This is the source of the feeling of the constant Jewish threat, which is the foundation for the phantasmic imperative: Self-defence, prevention, and rivalry unto death and after death. ${ }^{106}$

${ }^{101}$ Kapralski, “Battlefields of Memory...”, p. 39-40.

102 "I should recall the ethnographic cliché that every culture construes itself as the only one that is true and worthy of being called human" (Joanna Tokarska-Bakir, Legendy o krwi. Antropologia przesq̨du [Warsaw: W.A.B., 2008], p. 348).

${ }^{103}$ Ibidem, p. 592. "Celebrating Saturday was viewed as the opposite of celebrating Sunday by Christians. These inversions were even more apparent in the historical picture of a Jew. It was believed that Jews are born through the anus, that Jewish men menstruate and that women "open horizontally" (ibidem).

${ }^{104}$ The act of classification, similar in every archaic culture, universal and inherent to the structure of human consciousness, turned into an aggressive cultural pattern targeted against Jews at the time when Christianity was separating from Judaism. Theological dependence and personal identity explain Christian aggression towards Judaism characteristic of "the narcissism of little difference described by Freud, i.e. a tendency to exaggerate differences resulting from similarity and its threat to the sense of distinctiveness." (ibidem, p. 585).

${ }^{105}$ Apart from the narcissism of little difference, some Bible scholars point to a historical context in which, decades after Jesus's death, if not later, the anti-Jewish message of the holy scriptures of Christianity was born: "Gospels were written after a devastating Jewish insurgency against the Roman occupant in Jerusalem, resulting in a violent counterattack by the government on the Jewish community. Under such circumstances, gospel authors undoubtedly wished to separate a budding Christian community from the Jewish mainstream in order to protect it from Roman punishment" (John T. Pawlikowski, "Od takich biblistów uchowaj nas, Panie," Gazeta Wyborcza, 7-8 September 2013: 31). Martin Goodman, a prominent researcher on ancient civilisations, agrees with this view (cf. idem, Rome and Jerusalem: The Clash of Ancient Civilisations, New York: Knopf, 2007). Be that as it may, the spirit of Roman propaganda manifests itself in Gospel. After the siege and destruction of the Temple - the last bastion of insurgents in Jerusalem - Romans started depicting Jews as the enemies of mankind - hostes humani generis. These events are commemorated by the Arch of Titus, the conqueror of Jewish insurgents, in Rome. Representing left-wing Zionism, Nathan Rapoport engaged in a polemical dialogue with the Arc in his Ghetto Heroes Monument in Warsaw.

${ }^{106}$ In Christian representations, the rivalry is present not only in all areas of life but also in the afterlife: "Christian recollections of Jewish funerals have this indispensable element 
The confrontational location of the Monument to the Fallen and Murdered in the East vis-à-vis the Umschlagplatz monument created a symbolic axis, which I call for practical purposes the Muranów Axis. For diplomatic visitors and tourist the monuments are part of the same 'package' so much so that the Monument to the Fallen and Murdered in the East seems to have been erected as an extension of the Umschlagplatz monuments, as if to complete it. In both cases the point is to commemorate the deportations. The number of deportees is quite similar. The Soviet Union deported around 320,000 Polish citizens. The Third Reich - over 300,000 from the same area. The implied symmetry may therefore seem obvious. It does, however conceal the actual contrast between the two commemorated events.

From the Umschlagplatz people were deported to the East, in fact 'deported to the East' meant immediate indiscriminate death for the Jews. In the four waves of Soviet deportation into the hinterland of the USSR Polish citizens of different nationalities were resettled. Among them: 210,000 Poles, 70,000 Jews, and a total of 50,000 Ukrainians, Belarusians, Lithuanians, Germans, Russians and Tartars. ${ }^{107}$ By no means were all of them killed. The conditions for the deportees were horrific, potentially deadly, particularly for the elderly and the youngest children. But a decisive majority did survive. For the Polish Jews the Soviet deportations to the east and their subsequent suffering meant a chance to survive, whereas to remain where they had lived did not, and was practically tantamount to certain death, in a ghetto, a gas chamber or on the Aryan side. None of this is made visible to the observer, a participant in Polish culture in its majority, dominant form. In spite of specialist studies and postulates articulated in public debate on pre-war Poland and World War II, the citizens' perspective never penetrated the Siberian discourse or the Katyń discourse.

Another mental blockade was put on mass imagination by Andrzej Wajda's film, Katyń (2007). It depicts the victims of the Katyń massacre as a monolith

of rivalry between the dead who will compete for priority during the Final Judgement" (Tokarska-Bakir, Legendy o krwi..., p. 508). From the ethnographic interviews carried out by the team lead by Joanna Tokarska-Bakir on the area of Sandomierszczyzna (2005-2006) and on the Podlachia (2004-2006), among Roman Catholics and Eastern Orthodox Christians respectively, transpires that a burial of the dead in a shroud was supposed to secure that "when the Final Judgement begins, Jews will get up first and be first in line before goys can even rise from their coffins." Which is why Christians imagined Jews to be buried squatting or sitting, if not standing. The dead were supposed to be given sticks for some eschatological Nordic walking and bags of sand "in case goys overtake them in the race for the Judgement so they can throw some in their eyes" (ibidem). Alina Cała got similar results in her field research in south-eastern and eastern Poland in 1975, 1976, 1978 and 1984 (cf. eadem, Wizerunek Żyda w polskiej kulturze ludowej [Warsaw: Oficyna Naukowa, 2005], pp. 75-78).

${ }^{107}$ However, the total number of Polish prisoners of war and Polish citizens interned, arrested or deported may be estimated at about 475,000 people; about 33,000 of them were killed and about 25,000 died (cf. Piotr Eberhardt, Migracje polityczne na ziemiach polskich (1939-1950) [Poznań: Instytut Zachodni, 2010]). 
of the Roman Catholic faith and a personification of the Christ of the Nations. 108 The scene that shows the figure of crucified Jesus - in a crown of thorns and the overcoat of a Polish Army officer is among the most emblematic in Wajda's films. If one considers that the officer's overcoat bears the blue ribbon of the highest military decoration, the Virtuti Militari cross, most likely awarded for the Polish-Bolshevik war of 1919/1920, this figure also seems to communicate with the anti-Semitic themes of the anti-communist imaginarium, regardless of the artist's intentions.

In popular reception, the victims of deportations of 1940-1941 have been effectively 'Polonised' in the Polish mono-ethnic and mono-religious spirit. What one sees in the analysed juxtaposition of monuments is therefore symmetry of fates: Polish and Jewish. It means 'Holocaustisation' of the persecution of Poles by and in the USSR. ${ }^{109}$ What one has here as well is a smooth combination of the deportation discourse with the discourse of crime into one undifferentiated Siberian-Katyń discourse. ${ }^{110}$ That the discourse ignores the difference of the two combined events leads to an equalisation and homogenisation of their status. Thus the Muranów axis is an example of integrated 'Holocaustisation'.

This phenomenon has its counterpart in the public debate, but there it was divided into stages. The establishment of the Siberian-Katyń package came second. The original operation was the Holocaustisation of Katyń, ultimately

${ }^{108}$ Poland the Christ of the Nations - a topos / phantasm of crucial significance for Polish Messianism. It was given artistic expression by Adam Mickiewicz in Part III of Forefathers' Eve (Dziady). In the Christian religion the body of Christ is the Church, i.e. all its members. The identification of a community of faith with a national community is tantamount to identifying Christ with a nation, in this case with Poles and Poland. Poland and Poles, as the chosen people, are thus equipped with the eschatological mission to save the world.

${ }^{109}$ A pendant picture to the 'holocaustisation' of the suffering inflicted to Poles by the Third Reich (cf. works by Richard C. Lukas: Out of the Inferno. Poles Remember the Holocaust [Lexington: University Press of Kentucky, 1989], and Forgotten Holocaust: The Poles Under German Occupation, 1939-1944 [New York: Hippocrene Books, Inc., 1986]). On the procedure of holocaustisation, see Elżbieta Janicka, "Holocaustization. The Myth of the Warsaw Uprising in 'Kinderszenen' by Jarosław Marek Rymkiewicz," in Polish and Hebrew Literature and National Identity, eds. Alina Molisak, Shoshana Ronen (Warsaw: Dom Wydawniczy Elipsa, 2010), pp. 275-290 and eadem, “Mroczny przedmiot pożądania. O 'Kinderszenen' raz jeszcze - inaczej," Pamiętnik Literacki 4 (2010): 61-86. 'Holocaustisation' is the official policy of the Warsaw Rising Museum as reflected in its series of cultural events called "Warsaw - a City of Two Risings" and in the explanation its director gave for the outbreak of the rising: "This resistance was an answer to Germans who wanted Poles to share the fate of Jews. They wanted to remove us from the surface of the earth" ("Sprzeciw na gruncie moralności. Z Janem Ołdakowskim rozmawia Stanisław Żaryn," Sieci, 29 July - 4 August 2013, 65).

${ }^{110}$ Considering the fact that there is a missile shell filled with some earth from Vilnius, Lviv, Katyń, Starobilsk, Vorkuta and Siberia erected in the mound for the monument, one should rather call it a Kresovian-Siberian-Katyń discourse. 
legitimised by Poland's president Lech Kaczyński in his speech in 2009.111 The Holocaustisation procedure of the Katyn massacre by Poland's first citizen was not a proposition of a new interpretation, but it used us and crowned at the same time the process of extending the boundaries of discursive acceptability and formatting of collective memory, which has been continued at least since the 1980s.

British scholars stress that within the Polish Katyń discourse the equalisation of Nazism and Stalinism (if not with communism) was quite commonplace from the very beginning. On the other hand, in 1989 Polish public debate saw an articulation of the opinion quite common among the Katyn activists in Poland and abroad that the Katyn cemeteries should play the same role as Auschwitz, and that the Katyn Museum should be modelled after the Auschwitz Museum. ${ }^{112}$ In 2006, the then Polish minister of education, Roman Giertych, added that it would be necessary to introduce mandatory school trips to Katyń, as is the case with Israeli youths to former German concentration camps. ${ }^{113}$ This dignitary, a grandson of an extreme anti-Semitic ideologue, Jędrzej Giertych, and a proud scion of the nationalist line did nothing to hide his 'Holocaustisation' motive: "Israel does it and so we should follow the Jews". ${ }^{114}$

${ }^{111}$ It was one of two Presidential speeches at Westerplatte on 1 September 2009. When addressing veterans, members of the Polish government, Roman Catholic clergy and diplomatic corps, the President said: "The battles of the September Campaign lasted until October 6 in Kock. Then fell the night of the occupation. Its essence was in crime. Its essence was in Oświęcim, its essence was in Holocaust but also in Katyń. One might ask: how does the Holocaust inflicted by Nazi Germany compare to Katyń inflicted by Soviet Russia? Despite the drastic difference in their scope, there is one thing both these crimes have in common. Jews were dying because they were Jews. Polish officers died because they were Polish officers. Such was the sentence in both cases" (http://www.tvn24.pl/przemowienie-lecha-kaczynskiego-na-westerplatte,107474,s.html, access 1 September 2013). Unjustly, then, the 'holocaustisation' of Katyń is sometimes presented as a marginal phenomenon, a domain of fusty Polish National Party (Polska Partia Narodowa) led by Leszek Bubel, which supports two book series: Polski Holokaust (Polish Holocaust) and Poznaj Żyda (meet a Jew).

${ }^{112}$ Cf. Remembering Katyn, pp. 24, 25, 27 and the whole chapter "Katyn in Poland".

${ }^{113}$ Death camps were established and operated by agencies of the German state (Deutsches Reich). It is in this sense that I use the word 'German'. The citizens and the elites of the German state were Germans and, after 12 March 1938, Austrians.

${ }^{114}$ Aleksandra Pezda, "Pierwsza lekcja Giertycha," Gazeta Wyborcza, 5 September 2006, 3. Four years later, his idea was developed by Janusz Kochanowski, the Commissioner for Human Rights, in a letter to Katarzyna Hall, the Minister of National Education: "I would like to call for the inclusion of obligatory visits to the military cemetery in Katyń in school curricula". In his justification, he emphasised that "the memory of victims of totalitarian systems should be the highest imperative for Polish citizens, especially for children and youth" "Każda szkoła ma wysłać dzieci do Katynia," Dziennik Gazeta Prawna, 5 March 2010, http://wiadomosci. dziennik.pl/wydarzenia/artykuly/112840,kazda-szkola-ma-wyslac-dzieci-do-katynia.html, access 1 September 2013). After Janusz Kochanowski's death in the crash of the Presidential plane near Smolensk, the idea was kept alive by members of the Law and Justice (Prawo 
The Muranów axis, regardless of possible aesthetic or ethical judgments, remains an example of a success in persuasion. Analysed in terms of a visual message it effectively erases the differences between the Holocaust and the persecution of Poles in the Soviet Union. Instead of a dissonance and tension, it reveals a harmony founded on the symmetry of two allegedly equivalent qualities. The pattern of quality/anti-quality that can be seen in the opposition: military-Polish/civilian-Jewish does not seem to be primary in the juxtaposition of the two monuments. The departure from the rivalry model does have an ostensible character, because it takes place within the framework of a superior fundamental narrative.

\section{Katyń vis-à-vis the Holocaust}

Due to the very construction of the Muranów axis, a veritable symbolic pirouette is imposed on the implied simple symmetry of the allegedly equivalent qualities. Namely, the simple symmetry model is subject to a transformation into a complex symbolic model. The symbolic model does not take into consideration the factor of time, of chronology. The complex symmetric model emphasises temporal sequence, and thus it may imply the existence of a cause-and-effect that combines the juxtaposed events. The effected reconfiguration enables formulating far-reaching conclusions, from historiosophic conclusions to moral ones. What is interesting from this point of view is the social functioning of the Monument to the Fallen and the Murdered in the East.

Apart from veteran celebrations usually organised by the Siberian Exiles Union, every year a re-enactment of the Katyn massacre is held near the monument. ${ }^{115}$ This event is held in the second half of April. In 2009, it was exactly

i Sprawiedliwośc) party: "If we want to be the true Poles and pass the values our patriots died for to our children, we have to provide them with the minimum of historical education, argues Stanislaw Pięta in an interview with TOK FM. In his opinion, now, after the tragic death of the President in Smolensk, it is a perfect time to 'restore in youth the pride of being Polish, of being a brave nation"” ("Pomysł PiS: Obowiązkowa wycieczka do Katynia," Onet.pl - Wiadomości, 16 April 2010, access the same day). After formulating a parliamentary interpellation on obligatory trips to Katyń, members of parliament were to apply for obligatory trips to Wawel, the Auschwitz-Birkenau State Museum and the Warsaw Rising Museum. Three years later, the case resurfaced in a special issue for teachers published by an esteemed historical monthly: "Until a trip to Katyń is included in the basic curriculum of general education, there is not much left for us but to teach in a classroom" (Łukasz Myszka, "Katyń na lekcji historii," Mówiq Wieki w Szkole [2013]: 9 - a separate supplement to the April issue of Mówiq Wieki). It is yet another example of an unopposed leap of a topic from the outskirts of public sphere to the mainstream. Its supporters leave politics but their point of view stays unquestioned and, as the time goes by, becomes the obvious.

115 The re-enactment Group 'Radosław' specialises in re-enactments of the Katyń executions and events associated with a cult of the Cursed Soldiers. In the spring of 2012, on platform 4 of Warszawa Central Station, they prepared a diorama and a forest station evocative of 
on 19 April, on the anniversary of the Warsaw Ghetto Uprising. This proximity of dates, including their concurrence, appears purely accidental at first sight. But on closer inspection, is reveals a historical connection that dates back to 1943.

The Katyń massacre was a Soviet Stalinist state crime. It was carried out by the NKVD following the written decision of the Central Committee of the Bolshevik Party of 5 March 1940. The executions began less than a month later, on 3 April and continued through the spring months of that year. The mass graves may be found, among others, in Katyn near Smolensk, in Mednoe near Moscow, at Bykovnya near Kiev, and in Pyatykhatky near Kharkov, as well as, probably, near Minsk, so in today's Russia, Ukraine and Belarus, respectively. The victims were 21,857 interned Polish soldiers of several nationalities. Among them were Polish Army officers, policemen, physicians, functionaries of the Border Guard Corps and state officials. The victims of the Katyn massacre, subjected to the 'Polonisation' procedure, constitute the only category of prisoners of war embraced in Polish collective memory. ${ }^{116}$

The Germans discovered the mass graves in Katyn after the invasion of the Soviet Union, in October 1941, but for a year and a half it had no meaning for them at all. They remembered this only in the planning stages of the liquidation of the Warsaw Ghetto, which was a part of the industrial extermination of the Jews. The Nazis decided to march into the ghetto on 19 April 1943. It was then that the Jewish uprising broke out. Seven days before the Germans launched a propaganda campaign, coordinated by Joseph Goebbels, the minister of popular enlightenment and propaganda (Reichsministerium für Volksaufklärung und

the post-1945 Jew hunt (akcje wagonowe) organised by, i.a., the National Armed Forces (Narodowe Siły Zbrojne). Tomasz Karasiński, commander of the Re-enactment Group 'Radosław', proved relentless: "It is a tribute to the heroes. If it had not been for such people, today we would not be speaking Polish" (quoted in Iwona Szpala and Tomasz Urzykowski, "Pamięć w Dniu Wyklętych," Gazeta Wyborcza, supplement Gazeta Stołeczna, 28 February 2012, 2).

116 "The memory of the September soldiers and officers taken captive... is not a part of Polish collective memory. Polish memory of the defenders of Westerplatte (who "went straight to heaven in a coach-and-four" [trans. by Walter Whipple]) covers a period of only seven days, but the war in Europe took 2035 more days, and one does not know what happened to the defenders of Westerplatte during all that time [...] The trace of the soldiers, those fighting in the Battle of Hel, the Battle of the Bzura and the Battle of Kock, breaks off in our collective memory when they went in a coach-and-four not so much straight to heaven as to captivity, convoyed by Germans. On the map of our mentality, a heroic red contour line binds Westerplatte and Hel, Warsaw and Modlin, Mława and Kock, and Wizna; but if any contour line binds Gross Born and Woldenberg, Murnau and Prenzlau, Kreuzburg and Osterode as well as over thirty other names, it runs through the map of our collective 'disremembrance'. Probably the only prisoners of war saved from oblivion by Polish collective memory, or even cordially put on a pedestal, are those of over 20,000 people who lie in mass graves in Katyń, Kharkiv and Mednoye (and places yet undiscovered), martyrs to the national cause and the elite of Polish martyrology, who paid for their recognition with rivers of blood" (Wojciech Chlebda, "Wyspa z Archipelagu Oflag," Strony 3 [2009]: 67). 
Propaganda), together with Hitler. On 13 April 1943, the press and the radio informed that the Katyń massacre was a "Judaeo-Bolshevist ritual murder." When the Jews were dying in the flames of the Warsaw Ghetto, the press and the radio publicised witness's accounts of the 'Jewish' appearance or behaviour of the henchmen. A Pole, Feliks Dzierżyński, the architect of the Czeka-NKVD terror apparatus, had also been made a Jew.

Anti-Semitic Nazi propaganda combined the most ancient Christian beliefs with early forms of anti-Semitism. At Easter 1943 the following made themselves heard: the myth of the Jewish murderer of God, the myth of the Jewish perpetrator of ritual murder, and the myth of Judaeo-Bolshevism. On the streets of towns and hamlets in the General Government the poster entitled "Katyń" was put up, and it depicted an imaginary scene of the massacre: Polish Army officers and other uniformed personnel are being executed by men in NKVD uniforms, with a grin of satisfaction, and arms covered with blood. The executioners' faces are characteristic of anti-Semitic caricatures and cartoons, published, among others, by the Nazi periodical Der Stürmer. In brief, Polish prisoners of war are being executed by phantasmic Judaeo-Bolsheviks, the mythical Judaeo-communists. The poster was designed by the artist Theo Matejko, who worked for the Nazis. The poster was distributed in German-occupied Europe. Its French edition bore the caption "Le paradis sous terre", paradise under the ground, a clear reference and paraphrase of the communist promise of paradise on Earth (le paradis sur terre).

At Easter 2010, a Polish-language version the Nazi poster was exhibited in the lower part of the Warsaw Temple of Divine Providence, also called the Pantheon of Great Poles, by the grave of the chaplain of the Katyn Families, Father Zdzisław Peszkowski. In 2012, the poster was featured on the cover of Ale Historia, a historical supplement to Gazeta Wyborcza, ${ }^{117}$ where it bore an enigmatic annotation "German propaganda poster" - in order to present the historical reality of the Katyń massacre. ${ }^{118}$ In 2013, apart from its promotion in right-wing periodicals and on displays of so-called 'patriotic bookstores' all over Poland, Theo Matejko's work was reproduced twice in the April edition of

${ }^{117}$ The largest Polish daily of the liberal, democratic and free-market orientation, founded by the milieu of anti-communist opposition, associated with the Workers' Defence Committee. Since the first issue of 8 May 1989, the editor-in-chief has been Adam Michnik, a leading dissident in the Peoples' Republic of Poland.

${ }^{118}$ Asked to publish some explanation as to the character of the poster, Piotr Nehring, editor in chief of the "Ale Historia" supplement, informed me in writing about the role the disclosure of Katyń massacre played in the USSR severing diplomatic relations with the government in London and in the weakening of the Polish voice in the anti-Nazi coalition (cf. private correspondence of the author with Piotr Nehring). The editor's answer was irrelevant to both my letter and the article 'illustrated' with the Nazi poster. The text was devoted to fruitless Soviet attempts to depict Katyń as a Nazi crime during the Nuremberg trials (cf. Wacław Radziwinowicz, “Żelazna Maska - tajny więzień Stalina,” Ale Historia, 27 [February 2012]: 6-8). 


\section{Studies}

another mainstream historical magazine Mówiq Wieki. Once in a French language version, described as a 'poster distributed in German-occupied Europe - here in French'. Later, in Polish, now without a comment, in an educational supplement for middle school teachers Mówiq Wieki w Szkole. ${ }^{119}$ The April edition of the monthly was devoted to "Katyn - crime and lies". The seventieth anniversary of the Warsaw Ghetto Uprising was mentioned in the column Historical Telegraph in the context of the passive stance of Great Britain and the United States vis-à-vis the fate of the Warsaw Jews.

13 April was ceremoniously celebrated as early as the 1980s by certain opposition milieus. ${ }^{120}$ On the other hand, eighteen years after the political changes, in 2007, the Polish Sejm unanimously established a new holiday, the Day of the Memory of Victims of the Katyń Massacre. The media systematically mentioned the date when the news of the massacre was made public, that is 13 April $1943 .{ }^{121}$ The reference to 1940 remains in the background, as if the Katyn massacre itself was unimportant, and only counted as a media fact. Thus the residue of the Nazi ideological paradigm had been implanted under the surface of the public sphere of independent Poland, eo ipso its potential legitimising, instead of its criticism and overcoming. ${ }^{122}$ If treated thus, they preserve their status of symbolic dynamite, and with a minimal shift of accents, they could be easily detonated. Thus the question remains: what is the meaning and what are the stakes of this symbolic operation, regardless of whether it was carried out deliberately or whether it 'happened' as a result of historical inertia.

${ }^{119}$ Myszka, "Katyń na lekcji historii”, p. 11. The French version of the poster illustrates the article by Tadeusz Wolsza, “Wiosna 1943 roku," Mówiq Wieki (April 2013): 34.

${ }^{120}$ Cf. Przemysław Gasztołd-Seń, “Siła przeciw prawdzie. Represje aparatu bezpieczeństwa PRL wobec osób kwestionujących oficjalną wersję Zbrodni Katyńskiej," in Zbrodnia Katyńska w kręgu prawdy i kłamstwa, ed. Sławomir Kalbarczyk (Warsaw: IPN, 2010), pp. 145-146.

${ }^{121}$ Cf. Polish Press Agency (PAP), "65 lat temu ujawniono Katyń," Gazeta Wyborcza, 14 April 2008, 4; Hanna Sowińska, "Dziś mija 67 lat od odkrycia przez Niemców w Katyniu grobów polskich jeńców," 13 April 2012, www.pomorska.pl, access in October 2013. The same may be observed on a timeline opening a British monograph on the Katyń discourse in seven countries of Eastern Europe: "14 November 2007: Polish Sejm declares 13 April the 'Worldwide Day of Memory of Victims of the Katyn Crime'. The date marks the anniversary of the 1943 German announcement" (cf. Remembering Katyn, p. XXVII - Timeline).

${ }^{122}$ In some circles as well as in the media, mainstream included, April has become a month of Katyń commemoration; one structural look at a calendar of anniversaries reveals that it replicates the Muranow axis. Cf. already quoted in the 2013 issue of an opinion-forming history magazine Mówiq Wieki (2013 was the year of the $70^{\text {th }}$ anniversary of the Warsaw Ghetto Uprising). Cf. also April 2013 issue of Historia do Rzeczy monthly themed "Katyń 1940. Kim byli mordercy Polaków" (Katyń 1940. Murderers of Poles - who were they?). 


\section{Diachronic anterior Holocaustisation}

13 April 1943 marked the beginning of a Nazi anti-Semitic campaign, which not only aroused hatred, but also provided a rationalisation and moral alibi for crimes against Jews. This strategy was founded on the myth of JudaeoCommunists. Based on the extension of pre-war anti-Semitic propaganda of the Catholic Church and the National Democrats, which propagated the myth of Jewish Communists, the anti-Semitic Nazi propaganda found avid listeners among those Poles who, in various ways: in thoughts and in words, in what has been done and in what was not (words from the Catholic Penitential Act), supplemented the Nazi mechanism of destruction. As a result, in occupied Poland, on the 'Aryan' side, the Poles killed or brought about the death of more Jews than Germans. ${ }^{123}$ In 2000, following a nationwide debate on Jan Tomasz Gross's book Neighbors, and as a result of continued Holocaust research, the public discourse saw a quantum of knowledge of pre-war, wartime and post-war anti-Semitism, on the scale of robberies and denunciation, on the actual situation of the Righteous, on the 'industry of help,',124 on mass burnings at Jedwabne and other places, on the attitude of the Polish Underground State during the war and that of the armed underground after the war. As results of new research are published, knowledge on the subject becomes ever fuller and more available. Practically nobody denies it.

It would seem that the existing Polonocentric and martyrdom-heroic identity narrative cannot be maintained in the current circumstances. This is what Slavoj Žižek's theoretical model would imply:

123 "We know that about 200,000-250,000 Jews managed to escape from ghettos and wagons transporting them to extermination camps. About 40,000-60,000 survived. What happened to the rest of them? Did everyone die killed by Poles?... Even if half of the hiding Jews died of exhaustion, disease or lack of medical treatment (which is improbable), it will not change the significance of the crime. However, let us presume that the Grosses are indeed right and that Poles either killed with pitchforks and axes some umpteen thousand Jews or gave them away to the Nazis. This number is higher than the German toll during the September Campaign (17,000 killed) and much higher than the number of Wehrmacht soldiers killed in the Warsaw Rising (over 2,000 men). I do not know the estimates of German soldiers killed on the territory of occupied Poland from 1939 to the summer of 1944, when Operation Tempest began. Yet it is impossible to exceed 3,000. Having said that, what do the numbers given by the Grosses imply? Neither more nor less than that we, or at least the peasantry, were on a different side than we thought they were if we had killed more Jews than the Nazis" (Marcin Zaremba, "Biedni Polacy na żniwach," Gazeta Wyborcza, 15-16 January 2011,22 ). Writing about the countryside, the author seems to be underestimating the cities, where blackmail (szmalcownictwo) and denunciation were common (cf. Andrzej Żbikowski, "Posłowie," in Samuel Willenberg, Bunt w Treblince, posłowiem i przypisami opatrzył Andrzej Żbikowski [Warsaw: Biblioteka “Więzi”, 2004], p. 185).

${ }^{124}$ Quoted after Jan Grabowski (cf. idem, "Ratowanie Żydów za pieniądze - przemysł pomocy," Zagłada Żydów. Studia i materiały 4 [2008]: 81-110). 
[...] one should distinguish between symbolic history (the set of explicit mythical narratives and ideological-ethical prescriptions that constitute the tradition of a community, what Hegel would have called its 'ethical substance') and its obscene Other, the unacknowledgeable 'spectral', fantasmatic history that effectively sustains the explicit symbolic tradition, but must remain foreclosed if it is to be operative. ${ }^{125}$

Joanna Tokarska-Bakir adds: "The 'daytime' history of the Poles, filled with toxic martyrological clichés will not yield until the 'nocturnal' history of the Poles is revealed."126

Meanwhile, as it turns out, what hinders critical analysis and the working through of the past on a social scale is not ignorance of the 'nocturnal' history of the Poles, but a 'system of mental and moral organisation of this knowledge', where every problematic fact finds an 'easy explanation in a set of ideological myths, myths that are used to voluntarily blind oneself to reality".127 In other words, the problem is the socio-cultural framework: of perception and valuation, and in consequence of the narrative and memory. Confronted with the substantial knowledge, the existing 'day-time' history of the Poles, understood as the Polish dominant majority narrative, not only was undiminished but reinforced at the level of the main construction. Its defining simple symmetry developed into complex symmetry, while the synchronic Holocaustisation developed into diachronic anterior Holocaustisation.

The necessary elements of the new, or rather the newly configured, puzzle are the Polonised suffering of Polish citizens, victims of the USSR and the communists subjected to 'Judaisation'. From this point of view, Polish suffering at the hands of communists preceded the Holocaust and did not end with the war. ${ }^{128}$ To illustrate, Poland in the robes of the Christ of Nations went through the Golgotha at the hands of the communists. The majority Polish attitudes and behaviour towards the Jews were thus secondary and reactive in character. They were a response to Soviet occupation, deportations and Katyń. They also had the characteristic of prevention and self-defence before what was to come, and thus,

${ }^{125}$ Slavoj Žižek, The Fragile Absolute Or Why Is the Christian Legacy Worth Fighting for? (London-New York: Verso, 2000), p. 64.

${ }^{126}$ Tokarska-Bakir, "Mobilis in mobili..., p. 168. Besides, the term "night-time" is not too fortunate for the events usually took place in the broad daylight in a public space.

${ }^{127}$ Cf. Leszek Kołakowski, "Śmierć bogów," in idem, Pochwała niekonsekwencji. Pisma rozproszone sprzed roku 1968, vol. 2, selected and edited by Zbigniew Mentzel, foreword by Zbigniew Mentzel (London: Puls, 1989), p. 161-162.

${ }^{128}$ In a presidential speech delivered on September 1, 2009 in front of Russian Prime Minister and German Chancellor, a part on Katyń was introduced as follows: "The crime of the Holocaust was committed, but there were also other crimes committed before the outbreak of war between the USSR and Germany" (http://wpolityce.pl/wydarzenia/35236-westerplatte1-wrzesnia-2009-r-lech-kaczynski-w-obecnosci-putina-i-merkel-z-monachium-trzebawyciagnac-wnioski-imperializmowi-nie-wolno-ustepowac, access 1 September 2013). 
to recall another topos of Nazi propaganda, this time from the period following the Stalingrad and Kursk defeats, against "Jews returning with Bolshevism". The phantom of Jewish-communism was reactivated as an instrument of rationalisation and moral legitimisation of majority attitudes and behaviour toward the Jews during and after the Holocaust. Among the phenomena that are rationalised, normalised and morally legitimised, there were individual and collective crimes committed against Jews by the mainstream Polish underground, let alone its fringes.

To sum up, (simple) synchronic Holocaustisation is the presentation of a given event or historical period as a Holocaust in order to eliminate the distinctive features of the Holocaust and thus obtain other symbolic profits such as the restitution of a constitutive enemy that constitutes the group's identity and guarantees its cohesion. ${ }^{129}$ The constitutive regained enemy is the phantasmic Jew. Or, it could be any 'double' of the phantasmic Jew, equipped by the antiSemitic eye with attributes of phantasmic Jewishness, ${ }^{130}$ that is anyone who protests against Holocaustisation. Diachronic anterior 'Holocaustisation' (complex) is founded on (simple) synchronic 'Holocaustisation', but it concerns an event which: precedes the Holocaust, b) is allegedly the Jews' fault. To the symbolic benefits related to synchronic 'Holocaustisation' one might add, in this case, explanation and justification, being actually rationalising and legitimising the Holocaust and of the participation of one's own reference group in the Holocaust.

129 "It may be interpreted as an element of an utterly cynical strategy. After World War II, national memory based mostly on heroic narration still was a basic form of public memory" (Adam Ostolski, "Przestrzeń muzeum i polityka traumy," Kultura i Społeczeństwo 3 (2009): 67). Today, we observe an appetite for a victim mentality, which grew to become a political asset. In this context, a story about being a victim would appear as a new costume and a new symptom of nationalism, providing it with a new and more functional language. On the other hand, in 'holocaustisation', instead of a symptom or something next to it, one can spot a fetish, i.e. a phenomenon meant to cover something up. In this case, it would be a mask of fear that a non-problematic and essentialist national identity decays. The construction and upkeep of such a national identity are possible due to, or indeed conditioned by, the construct of an essentialist, invariable and timeless enemy" (Janicka, Mroczny przedmiot pożądania..., p. 80).

${ }^{130} \mathrm{~A}$ double is an individual who shares a part of the discredit due to "the tendency for a stigma to spread from the stigmatised individual to his close connections" (Erving Goffman, Stigma: Notes on the Management of Spoiled Identity (New York: Simon \& Schuster, Inc., 1963), p. 43). "Persons with a courtesy stigma provide a model of 'normalisation', e.g. showing how far 'normals' could go in treating the stigmatised person as if he didn't have a stigma... by treating the stigma as a neutral matter to be looked at in a direct, off-hand way, they [i.e. doubles - E.J.] open themselves and the stigmatised to misunderstanding by 'normals' who may read offensiveness into this behaviour" (ibidem, p. 44). Doubles practically eliminate the stigma. By managing without collective classifications, they expose the fact that it is inessential, hence they threaten the very foundations of collective identity. 
Neither of these anti-Semitic procedures is an exclusively Polish phenomenon. An analogous narrative current can be found in other countries of Eastern Europe. It is there, in lieu of denial, a way of administering Holocaust memory, which is more effective from the point of view of local socio-cultural underpinnings? The absence or actual isolation and marginalisation of denial, combined with anterior diachronic Holocaustisation of the fate of majority populations, appears to be a characteristic phenomenon in this region. For example, the Baltic states saw a marked presence of the idea that

Soviet repressions against Lithuanians, Latvians and Estonians were equal, in terms of brutality and the level of threat to Nazi repressions against the Jews, and thus they fulfil the definition of genocide (according to UN Convention of 9 December 1948), and therefore should be universally deemed as such. In certain cases this led to the so-called 'double genocide theory', which involved, apart from the view discussed above, the notion that the crimes against the Baltic peoples during 1940-1941 and 1944-1953, were committed by the security apparatus led by Soviet Jews. In the light of this position, murders and robberies, as well as other actions against the Jews (including their public humiliation), particularly in the early months of the war, after the German invasion of 22 June 1941 were a reprisal for repressions and deportations [...] and as such they can be deemed 'justified'. The stated double genocide theory in the Baltic expresses the view of those inhabitants of those countries who wish to compel their governments to compete for the title of the most persecuted nation in the entire European history, a nation threatened with complete eradication and abandoned by international public opinion. ${ }^{131}$

The notion of the red and the brown Holocaust (une Shoah rouge et une Shoah brune $^{132}$ ) satisfied the demand of the domestic memory market, and at the same time is an export commodity. This is because the matter culminates outside the borders of the states of the region. During 2005-2010, on the initiative of the Baltic states and Poland, the Parliamentary Assembly of the Council of Europe and the European Parliament debated on the equalisation of the two totalitarianisms, the equivalence of Nazi and Stalinist crimes (or, more broadly,

${ }^{131}$ Tomasz Stryjek, “'Wojna o pamięć” o wydarzeniach lat trzydziestych-pięćdziesiątych XX wieku w Europie Środkowej i Wschodniej w latach 2005-2010 - strategie polityki Litwy, Łotwy, Estonii, Ukrainy i Rosji," Kultura i Społeczeństwo 4 (2011): 199. The first weeks after 22 June 1941 are also the time of burnt offerings in a Łomża region, hence the "explanatory-justificatory" scheme in a Polish context seems even more appealing. Cf. also Philippe Perchoc, "Les mutations du compromis mémoriel européen. Une étude balte" in Georges Mink, Pascal Bonnard eds., Le Passé au présent. Gisements mémoriels et actions historicisantes en Europe centrale et orientale (Paris: Michel Houdiard Éditeur, 2010), pp. 55-67.

${ }^{132}$ Cf. Yitzhak Arad, "La réécriture de la Shoah en Lituanie d'après les sources lituaniennes," Revue d'Histoire de la Shoah, 197 (July-December 2012): 608, 646-647, 653-660. 
the so-called communist crimes) and on the right of the "victims and members of resistance movements in both totalitarian systems" to an equal place in the memory of extended Europe:

After a lengthy debate, the European Parliament adopted a resolution to establish a new holiday, being the European Day of Remembrance for Victims of Stalinism and Nazism on 23 August (the day of signing the Ribbentrop-Molotov Pact [...]), but did not accept the proposal of a group of deputies to establish the day of 25 May (anniversary of Witold Pilecki's execution) as the Day of the Heroes of Fight against Totalitarianism [...]. This meant that the victims of Nazism and Stalinism were deemed equal, without equating Nazi and Stalinist crimes. It seems that this refusal was, among others, a result of the fear of having the EU drawn into the attempts in the 'new' member states to elevate to the status of heroes those people who during 1939-1941 and/or 1944-1953 opposed the USSR, but during the German occupation collaborated with the Third Reich and/or took part in actions against the Jews (or at least hoped for Hitler's victory) ${ }^{133}$

The symbols game conducted by the new EU members admitted in 2004 is used to "shift the borders of the European memory compromise". ${ }^{134}$ Its integral part is rationalisation and legitimating the Holocaust within one's own sociocultural systems and the images of the community's past that they produce. The stake is the majority's self-image: the preservation of its heroic and martyrological identity narrative. ${ }^{135}$ Tomasz Stryjek articulates it more mildly when he speaks not about attempts to preserve the self-image of the victim

${ }^{133}$ Stryjek, “'Wojna o pamięć'..., p. 214-215. The fact that Witold Pilecki seemed présentable on a European stage only proves incomprehension of his report. It had been realised, however, that within the category "Heroes of the Fight against Totalitarianism", the captain became a vehicle for a symbolic promotion of rather dubious characters. It was the same mechanism that served using the Freedom and Independence organisation (Zrzeszenie 'Wolność i Niezawisłość, WiN) as a means to rehabilitate the National Armed Forces within category "Cursed Soldiers", but then again, one should start with establishing how it was that the WiN was rendered unproblematic if, "since 1946, there was no great difference between the WiN, the national camp, especially conspiring members of the National Party (Stronnictwo Narodowe, SN), and socialists in their approach to the Jewish question [...] Perceiving Jews above all, if not only, as danger was quite common and not only restricted to the radically anti-semitic part of the underground or even the underground itself [...] In the shadow of the fight for freedom and independence bred the beasts of anti-Semitism, people were killed just because they were Jews, Communists or supporters of the new order. Ideologism very often covered for ordinary banditry [...] The history of anti-communist conspiracy after 1944, if true, will not feed the legend" (Krystyna Kersten, "Rozważania wokół podziemia 1944-1947," in eadem, Między wyzwoleniem a zniewoleniem. Polska 1944-1956 (London: Aneks, 1993), pp. $42,44,91,94)$. Cf. also Rafał Wnuk, Lubelski Okręg AK DSZ i WiN 1944-1947 (Warsaw: Oficyna Wydawnicza Volumen, 2000).

${ }^{134}$ Perchoc, Les mutations du compromis mémoriel européen..., p. 62; my translation.

${ }^{135}$ Stryjek, “'Wojna o pamięć'...”, p. 198. 
and the hero, but about seeking to "balance off the image of the victim and the hero and the criminal". A tacit assumption behind this strategy is the denial of an inclusive definition of a nation as a civic community and the embracing of a religious and ethnic criterion of belonging to the group. Jews and those regarded as Jews regardless of one's identity choices, are, as before, subject to exclusion from the community.

The rationalisation of the Holocaust is closely intertwined with the normalisation of anti-Semitism, which is tantamount to legitimising it. It could also feed into Ernst Nolte's logic of gradual rehabilitation of Nazism (as expounded in the Historikerstreit), where anti-Semitism, together with the Endlösung der Judenfrage ('the final solution of the Jewish question') functions as an anti-communist redemptory civilizational mission, which in turn is an extension of Adolf Hitler's Mein Kampfand a copy of subsequent Nazi propaganda theses. In this sense, the rationalisation of the Holocaust is simply and positively correlated with the anti-communist paradigm, whose anti-Semitic potential is still inadequately researched and thus remains a danger. ${ }^{136}$ Meanwhile more and more monuments of Siberian exiles (and of the so-called 'Accursed Soldiers') are being erected, all with a declaratively anti-communist message. These items of remembrance are usually located in areas clearly related with the suffering and death of Jews. In this sense Warsaw, with a symbolic topography of the former Warsaw ghetto, proves to be representative for the country of which it is the capital. And so the narration of the anterior diachronic 'Holocaustisation' kind develops unhindered in an atmosphere of a moral crusade, and formats the symbolic landscape of today's Polish Republic.

Translated by Jerzy Giebułtowski

136 The anti-communist paradigm is based first on a lack of definitional precision and de-diversification, then on demonization, delegitimisation and application of double-standards against anything recognised, even arbitrarily, as communist. Thus, the rules of Bauhaus, the concept of social justice, shooting at workers, and Stalinist crimes, among many, end up in one terminological basket. The 1945-1989 period in the history of Central and Eastern Europe is subject to Stalinisation, and every act of violation is justified, or even viewed with pride, if only justified by anti-communist intentions. The contrast between Marxism disappears, viewed as a social philosophy and a school of critical analysis, and "Marlene" (Marxism-Leninism), which used to be, like anti-communism today, a false consciousness and a weapon against critical thinkers or those undermining the status quo. For an analysis of assumptions and stakes of the anti-communist paradigm, still rare after all these years, see Anna Zawadzka, “Żydokomuna. Szkic do socjologicznej analizy źródeł historycznych," Societas/Communitas 2 (2009): 199-243. Anna Zawadzka construes anti-communism not as a discourse but as a rule legitimising it. 


\begin{abstract}
A comparative analysis of the two monuments erected on one of the streets in the area of the former Warsaw Ghetto, the Umschlagplatz monument (1988) and the Monument to the Fallen and Murdered in the East (Pomnik Poległym i Pomordowanym na Wschodzie) (1995), shows how the equation of Nazism with Stalinism, if not with communism, has become inscribed in the symbolic topography of that place. The stake in this operation is the 'Holocaustisation' of the "Polish fate," epitomised by deportations into the interior of the USSR and the massacre in Katyń. The anticommunist discourse with a still un-defused anti-Semitic potential (the myth of Judaeo-communism, the double genocide theory) constitutes the overall narrative framework. The result is the rationalisation (presentation as a well deserved punishment or self-defence) of the stances of the majority of Polish society and its behaviour toward Jews during the Holocaust. Instead of upsetting the heroic-martyrological narratives about the dominant group's past, the increasing knowledge about the facts leads only to their mutation and strengthening. The context of this phenomenon is the politics of memory adopted by Poland and the Baltic states on the European forum. Its dynamic consists in shifting the limits of the European memory compromise, that is, in rationalisation of the Holocaust and antiSemitism in an attempt to preserve one's image as the hero and victim.
\end{abstract}

\title{
Key words
}

symbolic topography, politics of memory, double genocide theory, Holocaustisation, anti-Semitic discourse, myth of Judaeo-communism, Warsaw Ghetto, Katyń, monuments in the area of the former Warsaw Ghetto, Katarzyna Kobro's theory of spatial composition, Zofia and Oskar Hansens' Open Form 
